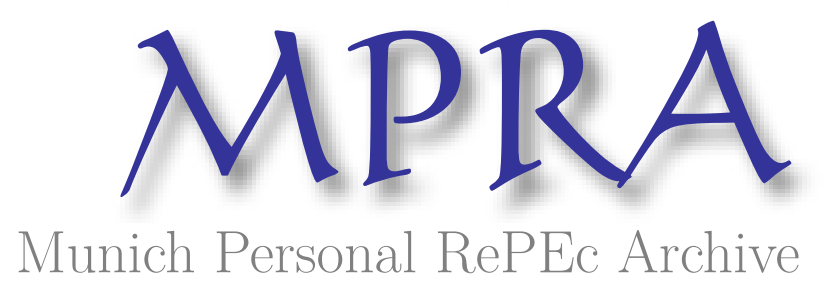

\title{
Export-orientation of Foreign Manufacturing Affiliates in India: Factors, Tendencies and Implications
}

Pradhan, Jaya Prakash and Das, Keshab and Paul, Mahua Institute for Studies in Industrial Development

August 2006

Online at https://mpra.ub.uni-muenchen.de/12338/

MPRA Paper No. 12338, posted 23 Dec 2008 13:24 UTC 


\section{Working Paper No: $2006 / 08$}

\section{EXPORT-ORIENTATION OF FOREIGN MANUFACTURING AFFILIATES IN INDIA}

Factors, Tendencies and Implications

Jaya Prakash Pradhan

Keshab Das

Mahua Paul 


\title{
EXPORT-ORIENTATION OF FOREIGN MANUFACTURING AFFILIATES IN INDIA Factors, Tendencies and Implications
}

\author{
Jaya Prakash Pradhan \\ Institute for Studies in Industrial Development \\ Keshab Das \\ Gujarat Institute of Development Research \\ Mahua Paul \\ Institute for Studies in Industrial Development
}

August 2006

Institute for Studies in Industrial Development

4, Institutional Area, Vasant Kunj, New Delhi - 110070

Phone/Fax: +91 112689 1111; E-mail: info@vidur.delhi.nic.in

Website: http://isid.org.in 
ISID Working Papers are meant to disseminate the tentative results and findings obtained from the on-going research activities at the Institute and to attract comments and suggestions which may kindly be addressed to the author(s). 


\section{Abstract}

This paper addresses an important development issue in literature of international production, namely what motivates market-seeking foreign direct investment (FDI) to undertake export activities. It is well recognized in the concerned literature that export-oriented FDI is more beneficial for the host country than purely domestic market-seeking FDI. Hence, many developing countries like India have policy concerns on foreign firms playing a very minimal role in their export activities. Various studies including that of UNCTAD (2003) noted that foreign direct investment (FDI) in Indian manufacturing has been and remains largely domestic market-seeking. In view of this low export contribution by foreign firms, existing studies suggest that developing countries like India should improve their locational advantages to attract export-oriented FDI as opposed to local market-oriented FDI like quality of available infrastructure, availability of cheap but skilled manpower, expanding the size of export processing zones, participation in bilateral/multilateral trade and investment regimes, etc. However, these studies have not examined those factors that could motivate the existing market-seeking FDI into export activities. The contribution of the present study is precisely to address this issue and identify factors encouraging market-seeking FDI to take up export activities. The empirical analysis has been conducted in two stages. In the first stage, we have estimated the export shares and export-orientation of foreign firms in Indian manufacturing across 17 Indian industries over 1991-2005. In the second stage, we have analyzed the impact of five set of factors-size and growth of host country market, local competition, policy regime, import competition and industry-characteristics on the export-orientation of foreign firms in Indian manufacturing. The empirical findings from the panel data analysis of 17 Indian industries over 1991-2005 has thrown up several policy implications important for increasing export-orientation of foreign firms in a developing country like India.

\section{Keywords}

Export-Orientation, Foreign Manufacturing Affiliates, Local Competition, Host Country Market. 


\section{Acknowledgements}

The paper is prepared for the sixth Development Convention, Madras Institute of Development Studies, 22-24 February 2007, Chennai, India. The study has benefited a great deal from useful discussions that we had with Professor K S Chalapati Rao. Particularly, his suggestion on the formulation of the empirical model has been extremely important for the study. The usual disclaimer applies. 


\section{CONTENTS}

Abstract $i$

Acknowledgements

Contents $\quad$ iii

$\begin{array}{ll}\text { 1. Introduction } & 1\end{array}$

2. Foreign Firms: Definition and Identification 3

3. Trends and Patterns of Export-orientation of Foreign Manufacturing Affiliates 4

3.1. Export Performance of Foreign Affiliates in Overall Manufacturing 4

3.2. Inter-industry Differences in Foreign Affiliates' Export Performance 6

3.2.1. Industry-wise Exports Volumes and Shares of Foreign Firms 6

3.2.2. Industry-wise Export-Intensity of Foreign Firms 9

3.2.3. Industrial Composition of Foreign Firms' Exports 12

4. Transformation of Market-seeking FDI into Export-oriented FDI:

Main Hypotheses $\quad 15$

H1. Host Country Market and Foreign Firms' Export-orientation 16

H2. Host Country Competition and Foreign Firms' Export-orientation 17

H3. Domestic Firms' Export Performance and Foreign Firms'

$\begin{array}{ll}\text { Export-orientation } & 18\end{array}$

H4. Import Competition and Foreign Firms' Export-orientation 18

H5. Host Country Policy Regime and Foreign Firms' Export-orientation 19

5. Data Sources and Methodology of Estimations 21

5.1. Data Sources $\quad 21$

5.2. Methods of Estimation $\quad 22$

5.3. Results and Inferences $\quad 24$

5.4. Impact of the New Policy Regime $\quad 27$

6. Conclusion and Policy Implications 29

References

$\begin{array}{ll}\text { Appendix Tables } & 34\end{array}$ 


\section{List of Figures}

Figure-1 Trends in Foreign Affiliates' Exports, Export Share, and

Export Intensity in Total Manufacturing

Figure-2 Export-Intensity of Foreign Firms (\%), 1991-1993 and 2003-2005

List of Tables

Table-1 Exports Share of Foreign Affiliates in Indian Manufacturing, 1991-2005

Table-2 Distribution of Number of Industries by Export Share

Table-3 Export-orientation of Foreign Affiliates and Domestic Firms in Indian Manufacturing

Table-4 Relative Export-orientation of Foreign Affiliates

Table-5 Sectoral Distribution of Foreign Affiliates' Exports from Indian Manufacturing, 1991-2005

Table-6 Determinants of Foreign Firms' Export-orientation 26

Table-7 New Policy Regime and Foreign Firms' Export-orientation 28

Table-A1 List of Firms Classified as Foreign-owned due to their affiliation to Foreign Groups 34

Table-A2 Number of Firms in the Sample $\quad 35$

Table-A3 Results from Collinearity Analysis I 36

Table-A4 Results from Collinearity Analysis II 37 


\title{
EXPORT-ORIENTATION OF FOREIGN MANUFACTURING AFFILIATES IN INDIA Factors, Tendencies and Implications
}

\author{
Jaya Prakash Pradhan", Keshab Das ${ }^{* *}$ and Mahua Paul ${ }^{* * *}$
}

\section{Introduction}

In the literature on export performance, it is generally recognized that foreign direct investment (FDI) can play an important role in the expansion of manufactured exports from developing countries. Multinational firms can bring with them the bundle of intangible assets like technology, skill, management know-how, brand names, and information on global market, which are critical factors for improving international market share. These assets, which are relatively scarcely available in developing countries, tend to strengthen the supply capacities of export-oriented industries in host countries. This is true especially when FDI itself is export-oriented in nature and generates knowledge-spillovers to domestic firms reducing the costs faced by them in breaking into international markets. They also provide access to global markets, especially developed country markets where they dominate the most ${ }^{1}$.

However, existing empirical evidence indicates that the export-enhancing role of FDI varies widely across developing countries. On the one hand, there is a set of developing and transition economies that have achieved substantial gains in global market share due to an important role being played by multinational corporations. For different years of 1990s, the foreign affiliates had contributed for more than 30 per cent of total exports from countries like China, Malaysia, Singapore, Chile, Hungary, Poland and Czech

* Institute for Studies in Industrial Development (ISID), New Delhi - 110 070; E-mail: pradhanjayaprakash@gmail.com

* Gujarat Institute of Development Research (GIDR), Ahmedabad - 380 060; E-mail: keshabdas@gmail.com

*** Institute for Studies in Industrial Development (ISID), New Delhi - 110 070; E-mail: p.mahua@gmail.com

1 An estimated two-thirds of world trade consists of trade involving multinational corporations (both intra-firm and third party transactions), and trade that take place within the same multinational is alone around one-third (UNCTAD 2002, pp. 152-153). 
Republic (UNCTAD 2002, Table-VI.3, p. 154). On the other hand, there is another group of developing countries like India where foreign affiliates have played a very minimal role in export activities, accounting for a share between 3-10 per cent of total manufacturing exports.

Most of the empirical studies that have explored the export-promoting role of foreign affiliates also have provided mixed findings across countries (see, Kumar and Siddharthan 1997, for a survey). In some countries, foreign firms had significantly contributed towards export performance of the hosts whereas in other countries their contribution is insignificant. Studies such as Sun (2001), Liu, et al. (2002), Liu and Shu (2003) and Pradhan (2005-06) on China; Ramstetter (1999a and b) on Hong Kong, Indonesia, Malaysia, Singapore and Taiwan; Lutz and Talavera (2004) on Ukraine; Jensen (2002) on Poland; Leichenko and Erickson (1997) on the U.S states have found a strong role of FDI in the host country export performance. Other sectoral studies like Siddharthan and Nollen (2004) on Indian information technology sector and Rasiah (2004) on electronics Industry in Malaysia, the Philippines and Thailand also have reported a positive role of foreign affiliates in export activities. However, there have been some studies, e.g., Kumar and Siddharthan (1994), Pant (1993) on Indian manufacturing; Chudnovsky and López (2004) on MERCOSUR countries, which suggest that foreign firms have played a relatively minor role in export promotion. Moreover, the exportenhancing role of FDI also seems to vary according to the shift in policy regime. In fact, most recent studies on Indian manufacturing relating to the reform period, for instance, Aggarwal (2002) and Kumar and Pradhan (2003) indicate that foreign firms have higher export-orientation than local firms.

What factors explain the above cross-country divergence in the export performance of foreign affiliates? Recent literature increasingly emphasizes the ability of countries to attract export-oriented FDI as opposed to market-seeking or local market-oriented FDI to explain country-specific differentials in foreign affiliates' export orientation. For example, countries such as China, Malaysia and Indonesia are argued to have been successful in attracting export-oriented FDI projects. Following this, aspirant developing countries are urged to address factors that would improve their attractiveness to export-oriented FDI. Studies dealing with the locational determinants of export-oriented FDI such as Woodward and Rolfe (1993) and Kumar (1994 and 1998) have underscored the role of structural factors like per capita income, availability of low cost labour, size of free trade/ export processing zones, quality of available infrastructure, participation in regional trading blocks, liberal trade regime, and tax benefits in attracting export-oriented FDI. Apart from the emphasis on improving these locational advantages, developing countries are also urged to adopt policies that improve access to imported inputs through 
trade facilitation, that rationalizes the use of fiscal and financial incentives according to efficacy and that conform to the international regulatory framework, that set up export processing zones, and that are targeted at and coherent in dealing with export-oriented FDI (UNCTAD 2002).

With the above backdrop, the present study proposes to analyze factors that determine export-orientation of foreign manufacturing affiliates in India. Unlike the existing literature on the subject that generally focuses on improving locational advantages from the point of view of attracting and leveraging export-oriented FDI for export performance, this study would examine those factors that could motivate the existing market-seeking FDI into export activities. The experience from Indian manufacturing would be relevant since there is a growing recognition in the literature that the FDI in Indian manufacturing has been and remains largely 'domestic market-seeking' (UNCTAD 2003, p. 43). The contribution of this study would be policy relevant as identification of various factors influencing (encouraging/discouraging) market-seeking FDI to take up export activities reveals distinct tendencies in the export scenario of the liberalizing host country, India.

The study is organized as follows: Section 2 deals with criteria to identify a firm as foreign owned. Trends and patterns of export-orientation of foreign manufacturing affiliates are analyzed in Section 3. Section 4 spells out main hypotheses to be tested in the study and formulate the empirical approach to identify determinants of foreign firms' export activities. Data sources, methodology of estimation and results are discussed in Section 5 . Section 6 concludes the paper with the listing of key policy implications.

\section{Foreign Firms: Definition and Identification}

A foreign enterprise can be defined as that enterprise where overseas investors have a lasting interest in it and a say in its management. Domestic enterprises, on the other hand, those promoted by purely domestic investors and, hence, their management is independent of any overseas influence. These domestic firms may have foreign portfolio investments in their equity capital but not cross-border direct investments.

For identifying foreign firms in empirical studies, most of the researchers including those belonging to the Organisation for Economic Co-operation and Development (OECD) and the International Monetary Fund (IMF), have conveniently assumed a minimum cut-off limit of the ownership that a foreign investor must possess to have a lasting and effective interest in a company. For example, as per the OECD if a foreign investor owns 10 per cent or more of the ordinary shares or voting power of an enterprise, then that enterprise 
is an FDI enterprise (OECD Benchmark Definition of Foreign Direct Investment, Third Edition, 1999). This equity based classification is also quite popular among Indian scholars although they have adopted different levels of equity participation to define a foreign firm in the past.

The Companies Act 1956 identified a company as foreign subsidiary if more than 50 per cent of the equity capital is held by a single foreign company. Similarly, Ganesh (1997) has treated a firm as foreign-controlled if its majority equity (more than 50 per cent) is held abroad. The Reserve Bank of India (RBI) in its studies on finances of joint stock companies used a cut-off of 25 per cent of equity held by a single foreign company or if 40 per cent is held in one foreign country to designate a firm as foreign-controlled. Kumar (1994) identifies a firm as foreign-controlled if 25 per cent or more of its equity is held abroad. Since 1992, the RBI has been following the guideline for identifying foreign direct investment enterprises prescribed by the IMF in its Balance of Payments Manual. In the present study, we have classified a company as a foreign affiliate if the foreign equity share in that firm is at least 10 per cent. Consequently, when firms have a foreign equity of less than 10 per cent, they are identified as domestic-owned companies. Therefore, we have also employed an equity-based criterion to identify foreign firms that have the usual limitation of ignoring non-equity channels of having effective say in management by foreign investors.

\section{Trends and Patterns of Export-orientation of Foreign Manufacturing Affiliates}

\subsection{Export Performance of Foreign Affiliates in Overall Manufacturing}

As discussed in the previous Section, the relevant literature points to the tendency of foreign affiliates in Indian manufacturing to be mostly local market oriented and have least biases towards export activities. This has led to a scenario whereby foreign firms are associated with low levels of export intensity and have marginal share in total exports from the manufacturing sector. Has there been any change in the export performance of foreign firms over the past 15 years? Figure-1 summarizes trends in the export performance of foreign affiliates in Indian manufacturing over five time periods viz 199193, 1994-96, 1997-99, 2000-02 and 2003-05. It can be seen that the magnitude of exports from total manufacturing by foreign affiliates has risen consistently from about Rs. 7536 crore in 1991-93 to Rs. 61159 crore in 2003-05. This increased quantum of exports by foreign affiliates is due to a spurt in their export-orientation. The share of exports in the total sales of foreign firms has gone up from 7.3 per cent in 1991-93 to 12 per cent in 2003-05. It appears that foreign affiliates are now more motivated to undertake export 
activities as compared to the past. The implementation of economic reforms, exportoriented policy regime, establishment of special economic zones, a receptive foreign investment regime, improvement in physical and skill infrastructure, etc. might have improved India's attractiveness as an export platform and foreign affiliates are positively affected by these developments. The higher growth rates of Indian industries and rising exports performance may have influenced foreign affiliates to explore export potentials.

However, in spite of the increased quantum of exports by foreign affiliates, their share in total exports from the Indian manufacturing still remains within the range of 7 to 9 per cent with a marginal negative bias. As large number of domestic firms have taken up export activities in the face of growing competition infused by liberalization, their relatively better export performance seems to have overshadowed the export share of foreign affiliates in the manufacturing sector. Nevertheless, a fairly impressive move in the export intensity from about 7 per cent to 12 per cent during the 15-year period does establish a clear improvement in the export efforts of foreign affiliates in India.

Figure-1

Trends in Foreign Affiliates' Exports, Export Share, and Export Intensity in Total Manufacturing

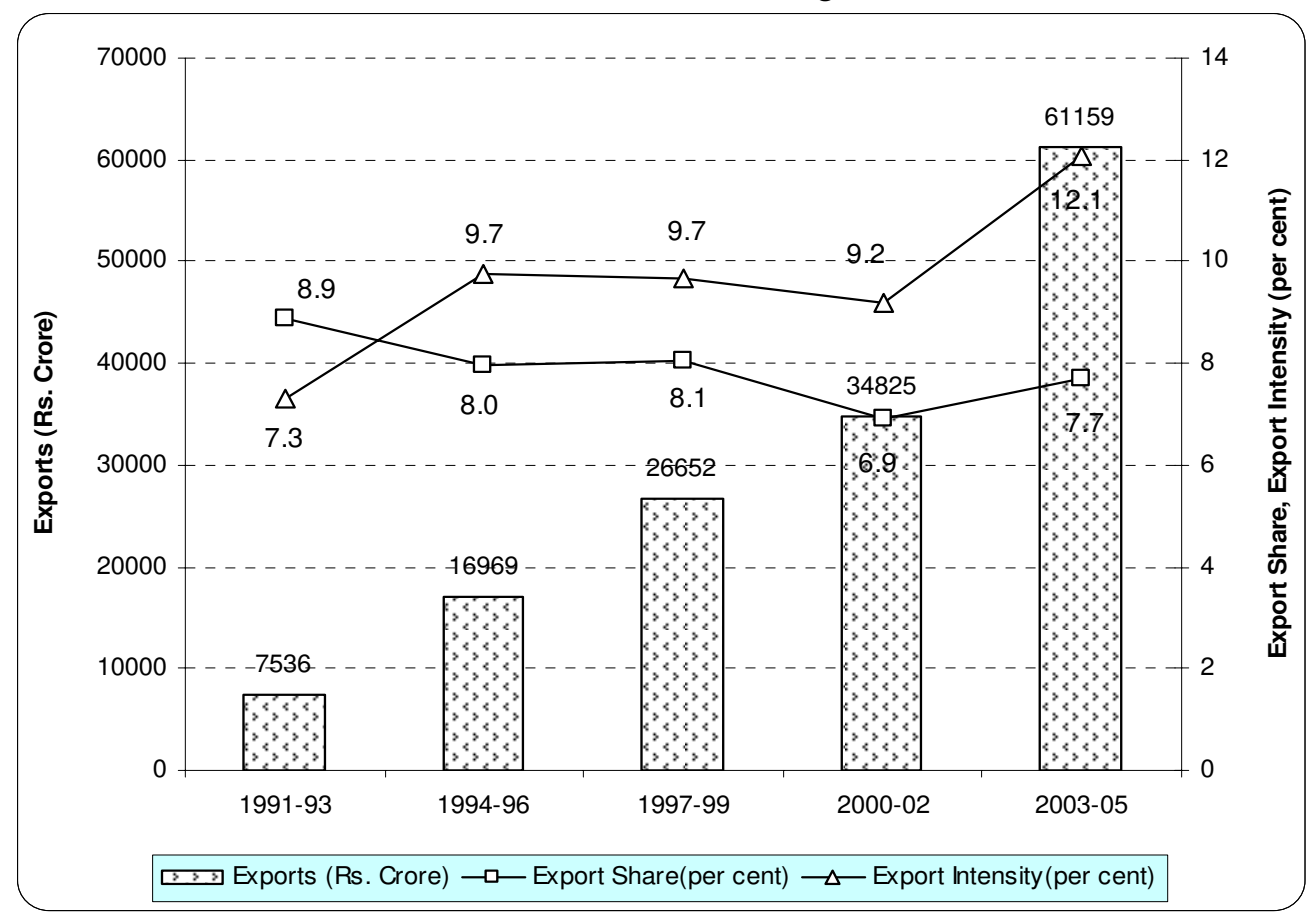

Source: Based on Table-1 


\subsection{Inter-industry Differences in Foreign Affiliates' Export Performance}

\subsubsection{Industry-wise Exports Volumes and Shares of Foreign Firms}

In line with the trends observed in the case of overall manufacturing, foreign affiliates have recorded very high levels of exports across individual industries. The level of exports during 2003-05 in all the 17 industries has been over eight times larger than the corresponding Figure-during the years, 1991-93. Although the low initial values might have contributed to an apparently big jump, it clearly suggests that the export propensities of foreign affiliates have certainly fared better over the years (Table-1). Among the 17 sectors shown in Table-1, three sectors such as Basic metals and fabricated metal products; Office, accounting and computing machinery; and Ships and boats, railroad equipment and transport equipment have experienced the steepest rise in the exports of foreign firms. Particularly, in the case of Basic metals and fabricated metal products, the export of foreign firms is aggregated at Rs. 14310 crore in 2003-05, which is 102 times the value of exports (Rs. 140 crore) in 1991-93. The programme of policy liberalization with respect to FDI, like putting the Basic metal and fabricated metal under the automatic approval route and successive enlargement of foreign equity holding limit, has led to considerable expansion of the existing and new foreign entrants into the sector and that has contributed to the rising exports of metal and fabricated products ${ }^{2}$. The export of foreign firms in Office, accounting and computing machinery sector has risen 44 times from just Rs. 74 crore in 1994-96 to Rs. 3203 crore in 2003-05. This sector is host to a total of four foreign firms, namely ACI Infocom, Moser Baer, Redington and X O Infotech specializing in computer peripherals and floppy disks and these firms are highly export-oriented. Similarly, the export from the Ships and boats, railroad equipment and transport equipment sector has grown 38 times between 1991-93 and 2003-05, thanks to three export-oriented foreign affiliates such as Automotive Coaches \& Components Ltd., Chokhani International Ltd. and Hero Honda Motors Ltd.

There are significant inter-industry differences in the percentage contribution of foreign firms in individual industries' total export from India. During 1991-93, foreign firms contributed marginally (less than 10 per cent export share) for the exports of eight industries, moderately (10-25 per cent export share) for eight industries and highly (more than 50 per cent export share) for two industries (Table-2). During 2003-05, the respective

2 Under the New Industrial Policy Statement of July 1991, manufacture of iron ore pellets, pig iron, semi-finished iron and steel were eligible for automatic approval of FDI up to 51 per cent of total equity. In December 1996, they were allowed automatic approval of FDI up to 74 per cent. The foreign equity limit was further raised to 100 per cent for iron and steel industry in 2006. 
number of industries with marginal export shares has grown to 10, those with moderate export shares has declined to six and those with high export share group have remained unchanged at two. This shows that the export contribution of foreign firms in large number of Indian industries is either marginal or moderate. In fact, the 50 per cent plus exports contribution by foreign firms is confined to just two industries in both 1991-93 (Electrical machinery and apparatus and Motor vehicles, trailers and semi-trailers) and 2003-05 (Office, accounting and computing machinery and Motor vehicles, trailers and semi-trailers).

Table-1

Exports Share of Foreign Affiliates in Indian Manufacturing, 1991-2005

\begin{tabular}{|c|c|c|c|c|c|c|}
\hline \multirow[t]{2}{*}{ NIC-98 } & \multirow[t]{2}{*}{ Description } & \multicolumn{5}{|c|}{$\begin{array}{c}\text { Foreign Firms' Exports in Rupees Crore } \\
\text { (As a \% of Total Exports) } \\
\text { Number of Foreign Firms }\end{array}$} \\
\hline & & $1991-93$ & 1994-96 & 1997-99 & $2000-02$ & 2003-05 \\
\hline (1) & (2) & (3) & (4) & (5) & (6) & (7) \\
\hline $15-16$ & $\begin{array}{l}\text { Food products, } \\
\text { beverages and } \\
\text { tobacco }\end{array}$ & $\begin{array}{c}2402 \\
(23.2) \\
34\end{array}$ & $\begin{array}{c}4122 \\
(15.6) \\
47 \\
\end{array}$ & $\begin{array}{c}5439 \\
(13.4) \\
55\end{array}$ & $\begin{array}{c}4726 \\
(10.2) \\
52 \\
\end{array}$ & $\begin{array}{c}5941 \\
(11.1) \\
42\end{array}$ \\
\hline $17-19$ & $\begin{array}{l}\text { Textiles, textile } \\
\text { products, leather } \\
\text { and footwear }\end{array}$ & $\begin{array}{c}502 \\
(1.3) \\
14\end{array}$ & $\begin{array}{c}1562 \\
(1.9) \\
23\end{array}$ & $\begin{array}{c}2579 \\
(2.1) \\
26 \\
\end{array}$ & $\begin{array}{c}2785 \\
(1.6) \\
31 \\
\end{array}$ & $\begin{array}{c}3760 \\
(1.8) \\
27\end{array}$ \\
\hline $20-22$ & $\begin{array}{l}\text { Wood, pulp, paper, } \\
\text { paper products, } \\
\text { printing and } \\
\text { publishing }\end{array}$ & $\begin{array}{c}75 \\
(18.6) \\
7\end{array}$ & $\begin{array}{c}161 \\
(10.5) \\
11\end{array}$ & $\begin{array}{c}176 \\
(8.4) \\
9\end{array}$ & $\begin{array}{c}339 \\
(8.9) \\
13\end{array}$ & $\begin{array}{c}413 \\
(6.1) \\
12\end{array}$ \\
\hline 23 & $\begin{array}{l}\text { Coke, refined } \\
\text { petroleum products } \\
\text { and nuclear fuel }\end{array}$ & $\begin{array}{c}2 \\
(11.9) \\
5\end{array}$ & $\begin{array}{c}10 \\
(10.2) \\
6 \\
\end{array}$ & $\begin{array}{c}20 \\
(0.9) \\
6 \\
\end{array}$ & $\begin{array}{c}13 \\
(0.1) \\
8 \\
\end{array}$ & $\begin{array}{c}33 \\
(0.1) \\
5\end{array}$ \\
\hline 25 & $\begin{array}{l}\text { Rubber and plastics } \\
\text { products }\end{array}$ & $\begin{array}{c}218 \\
(14.9) \\
13\end{array}$ & $\begin{array}{c}585 \\
(10.2) \\
20 \\
\end{array}$ & $\begin{array}{c}706 \\
(10.3) \\
22 \\
\end{array}$ & $\begin{array}{c}641 \\
(6.8) \\
24 \\
\end{array}$ & $\begin{array}{c}1185 \\
(7.5) \\
17 \\
\end{array}$ \\
\hline 26 & $\begin{array}{l}\text { Other non-metallic } \\
\text { mineral products }\end{array}$ & $\begin{array}{c}29 \\
(3.7) \\
13\end{array}$ & $\begin{array}{c}180 \\
(5.8) \\
17 \\
\end{array}$ & $\begin{array}{c}167 \\
(3.7) \\
17 \\
\end{array}$ & $\begin{array}{c}180 \\
(2.3) \\
19 \\
\end{array}$ & $\begin{array}{c}579 \\
(4.8) \\
19 \\
\end{array}$ \\
\hline $27-28$ & $\begin{array}{l}\text { Basic metals and } \\
\text { fabricated metal } \\
\text { products }\end{array}$ & $\begin{array}{c}140 \\
(2.5) \\
19\end{array}$ & $\begin{array}{c}1683 \\
(12.5) \\
29 \\
\end{array}$ & $\begin{array}{c}2518 \\
(12.2) \\
33 \\
\end{array}$ & $\begin{array}{c}4047 \\
(11.8) \\
34 \\
\end{array}$ & $\begin{array}{c}14310 \\
(18.2) \\
32\end{array}$ \\
\hline $351+352+359$ & $\begin{array}{l}\text { Ships and boats, } \\
\text { railroad equipment, } \\
\text { and transport } \\
\text { equipment, n.e.c. }\end{array}$ & $\begin{array}{c}10 \\
(0.9) \\
3\end{array}$ & $\begin{array}{c}84 \\
(3.1) \\
3\end{array}$ & $\begin{array}{c}163 \\
(5.2) \\
3\end{array}$ & $\begin{array}{c}120 \\
(2.5) \\
3\end{array}$ & $\begin{array}{c}395 \\
(5.1) \\
2\end{array}$ \\
\hline 29 & $\begin{array}{l}\text { Machinery and } \\
\text { equipment, n.e.c. }\end{array}$ & $\begin{array}{c}752 \\
(24.2) \\
45\end{array}$ & $\begin{array}{c}1071 \\
(17.4) \\
54 \\
\end{array}$ & $\begin{array}{c}1690 \\
(16.4) \\
52\end{array}$ & $\begin{array}{c}2799 \\
(17.4) \\
59 \\
\end{array}$ & $\begin{array}{c}3984 \\
(13.1) \\
54\end{array}$ \\
\hline
\end{tabular}




\begin{tabular}{|c|c|c|c|c|c|c|}
\hline \multirow[t]{2}{*}{ NIC-98 } & \multirow[t]{2}{*}{ Description } & \multicolumn{5}{|c|}{$\begin{array}{c}\text { Foreign Firms' Exports in Rupees Crore } \\
\text { (As a \% of Total Exports) } \\
\text { Number of Foreign Firms }\end{array}$} \\
\hline & & $1991-93$ & $1994-96$ & 1997-99 & $2000-02$ & $2003-05$ \\
\hline (1) & (2) & (3) & (4) & (5) & (6) & (7) \\
\hline 24 excl. 2423 & $\begin{array}{l}\text { Chemicals } \\
\text { excluding } \\
\text { pharmaceuticals }\end{array}$ & $\begin{array}{c}1378 \\
(24.6) \\
46\end{array}$ & $\begin{array}{c}2939 \\
(19.1) \\
57\end{array}$ & $\begin{array}{c}5494 \\
(19.9) \\
65\end{array}$ & $\begin{array}{c}8759 \\
(19.2) \\
69\end{array}$ & $\begin{array}{c}8862 \\
(10.7) \\
66\end{array}$ \\
\hline 34 & $\begin{array}{l}\text { Motor vehicles, } \\
\text { trailers and semi- } \\
\text { trailers }\end{array}$ & $\begin{array}{c}1007 \\
(52.7) \\
36\end{array}$ & $\begin{array}{c}2140 \\
(47.2) \\
39 \\
\end{array}$ & $\begin{array}{c}3243 \\
(48.7) \\
40 \\
\end{array}$ & $\begin{array}{c}3346 \\
(43.5) \\
44 \\
\end{array}$ & $\begin{array}{c}9676 \\
(51.9) \\
41 \\
\end{array}$ \\
\hline 31 & $\begin{array}{l}\text { Electrical } \\
\text { machinery and } \\
\text { apparatus, n.e.c. }\end{array}$ & $\begin{array}{c}513 \\
(56.9) \\
17\end{array}$ & $\begin{array}{c}1154 \\
(47.4) \\
19 \\
\end{array}$ & $\begin{array}{c}1577 \\
(33.1) \\
20 \\
\end{array}$ & $\begin{array}{c}2529 \\
(29.0) \\
20 \\
\end{array}$ & $\begin{array}{c}2754 \\
(17.5) \\
19 \\
\end{array}$ \\
\hline 33 & $\begin{array}{l}\text { Medical, precision } \\
\text { and optical } \\
\text { instruments }\end{array}$ & $\begin{array}{c}24 \\
(6.9) \\
4\end{array}$ & $\begin{array}{c}91 \\
(9.5) \\
10 \\
\end{array}$ & $\begin{array}{c}186 \\
(9.5) \\
11 \\
\end{array}$ & $\begin{array}{c}262 \\
(6.0) \\
10 \\
\end{array}$ & $\begin{array}{c}410 \\
(5.5) \\
7 \\
\end{array}$ \\
\hline 32 & $\begin{array}{l}\text { Radio, TV and } \\
\text { communications } \\
\text { equipment }\end{array}$ & $\begin{array}{c}58 \\
(11.7) \\
10\end{array}$ & $\begin{array}{c}112 \\
(4.6) \\
14 \\
\end{array}$ & $\begin{array}{c}590 \\
(13.0) \\
19 \\
\end{array}$ & $\begin{array}{c}597 \\
(9.5) \\
19 \\
\end{array}$ & $\begin{array}{c}908 \\
(9.5) \\
18\end{array}$ \\
\hline 30 & $\begin{array}{l}\text { Office, accounting } \\
\text { and computing } \\
\text { machinery }\end{array}$ & $\begin{array}{c}0 \\
(0.0) \\
0\end{array}$ & $\begin{array}{c}74 \\
(4.6) \\
2 \\
\end{array}$ & $\begin{array}{c}204 \\
(8.7) \\
4 \\
\end{array}$ & $\begin{array}{c}1082 \\
(30.7) \\
4 \\
\end{array}$ & $\begin{array}{c}3203 \\
(63.2) \\
3 \\
\end{array}$ \\
\hline 2423 & Pharmaceuticals & $\begin{array}{c}425 \\
(20.5) \\
27\end{array}$ & $\begin{array}{c}829 \\
(16.8) \\
37 \\
\end{array}$ & $\begin{array}{c}1565 \\
(18.7) \\
34 \\
\end{array}$ & $\begin{array}{c}2081 \\
(15.9) \\
40 \\
\end{array}$ & $\begin{array}{c}3851 \\
(16.7) \\
28 \\
\end{array}$ \\
\hline $36-37$ & $\begin{array}{l}\text { Manufacturing, } \\
\text { n.e.c }\end{array}$ & $\begin{array}{c}0 \\
(0.0) \\
0\end{array}$ & $\begin{array}{c}172 \\
(0.4) \\
2 \\
\end{array}$ & $\begin{array}{c}336 \\
(0.5) \\
2 \\
\end{array}$ & $\begin{array}{c}520 \\
(0.5) \\
2 \\
\end{array}$ & $\begin{array}{c}895 \\
(0.5) \\
2\end{array}$ \\
\hline All Industries & 15-37) & $\begin{array}{c}7536 \\
(8.9) \\
293\end{array}$ & $\begin{array}{c}16969 \\
(8.0) \\
390\end{array}$ & $\begin{array}{c}26652 \\
(8.1) \\
418 \\
\end{array}$ & $\begin{array}{c}34825 \\
(6.9) \\
451\end{array}$ & $\begin{array}{c}61159 \\
(7.7) \\
394 \\
\end{array}$ \\
\hline
\end{tabular}

Source: Computed based on two data sources: (i) exports of foreign firms have been abstracted from the Prowess database (Release 2), Centre for Monitoring Indian Economy (CMIE) after classifying firms into ISIC rev.3 using the detailed product description available in the database and (ii) industrywise total exports has been obtained from the 4-digit HS exports data from the India Trades (Version 2.0) of the CMIE by using a concordance, developed in-house, between HS 1996 (4-digit) and ISIC Rev.3 (3-digit).

Notes: Other transport equipments (35) include 351+352+359 and does not include 353 (Aircraft and spacecraft).

Another inter-temporal feature of the export contribution by foreign firms summarized in Table-1 is that in 11 industries their export share has fallen between 1991-93 and 200305, has remained unchanged in two industries and has increased in just four industries. The sharp fall in the export contribution of foreign firms during the same period has been in the case of seven industries, namely Electrical machinery and apparatus (from 56.9 per 
cent to 17.5 per cent); Chemicals (from 24.6 per cent to 10.7 per cent); Wood, pulp, paper, paper products, printing and publishing (from 18.6 per cent to 6.1 per cent); Food products, beverages and tobacco (from 23 per cent to 11 per cent); Coke, refined petroleum products (from 11.9 per cent to 0.1 per cent); Machinery and equipment (from 24 per cent to 13 per cent); and Rubber and plastics products (from 14.9 per cent to 7.5 per cent). Noticeable improvement in the export shares of foreign firms between 1991-93 and 2003-05 can be observed in the case of three industries viz Office, accounting and computing machinery (from 4.6 per cent in 1994-96 to 63.2 per cent), Basic metals (from 2.5 per cent to 18 per cent), and Ships and boats, railroad equipment and transport equipment (from 0.9 per cent to 5 per cent). Since foreign firms' export share has declined significantly in large number of industries as compared to their improvement in a few industries, their export share has declined in the overall manufacturing sector, an observation made earlier.

Table-2

Distribution of Number of Industries by Export Share

\begin{tabular}{|l|c|c|c|c|c|c|}
\hline \multicolumn{1}{|c|}{ Export Share (\%) } & \multicolumn{3}{|c|}{ 1991-93 } & \multicolumn{2}{|c|}{ 2003-05 } \\
\hline No. & Percentage & $\begin{array}{l}\text { Cumulative } \\
\text { percentage }\end{array}$ & No. & Percentage & $\begin{array}{c}\text { Cumulative } \\
\text { percentage }\end{array}$ \\
\hline Marginal (Less than 10\%) & 8 & 44.4 & 44 & 10 & 55.5 & 56 \\
\hline Moderate (10\% to 25\%) & 8 & 44.4 & 89 & 6 & 33.3 & 89 \\
\hline High (50\% and Above) & 2 & 11.1 & 100 & 2 & 11.1 & 100 \\
\hline All & 18 & 100 & - & 18 & 100 & \\
\hline
\end{tabular}

Source: Based on Table-1

In totality, these results indicate that in spite of foreign firms significantly pushing up levels of their exports during 1991-93 to 2003-05 in most individual industries, their export shares have declined. This is mainly because of relatively better export performance by the domestic enterprises.

\subsubsection{Industry-wise Export-Intensity of Foreign Firms}

Between 1991-93 and 2003-05, there have been significant improvements in the sectoral export orientation of foreign affiliates (Figure-2, Table-3). Of the 17 industries, in seven industries foreign firms nearly doubled their export intensity. They are 'Wood, pulp, paper, paper products, printing and publishing'; 'Rubber and plastics products'; 'Textiles, textile products, leather and footwear'; 'Chemicals', 'Ships and boats, railroad equipment and transport equipment, Machinery and equipment'; and 'Electrical machinery and apparatus'. In another two industries such as 'Pharmaceuticals' and 'Medical, precision and optical instruments', foreign affiliates' export intensity tripled in 
magnitude. Their export intensity quadrupled in other two industries, namely 'Other non-metallic mineral products' and 'Radio, TV and communications equipment'. Further, in the case of 'Basic metals', export intensity of foreign firms rose even faster by 7 and 12 folds respectively. However, the export intensity of foreign affiliates in 'Food products, beverages and tobacco' has fallen from 10.8 per cent in 1991-93 to 8.7 per cent in 2003-05. Overall, these trends suggest that there has been an all-round reshaping of the marketorientations of foreign affiliates who are substantially embedding their export platform activities in the Indian manufacturing.

Figure-2

Export-Intensity of Foreign Firms (\%), 1991-1993 and 2003-2005

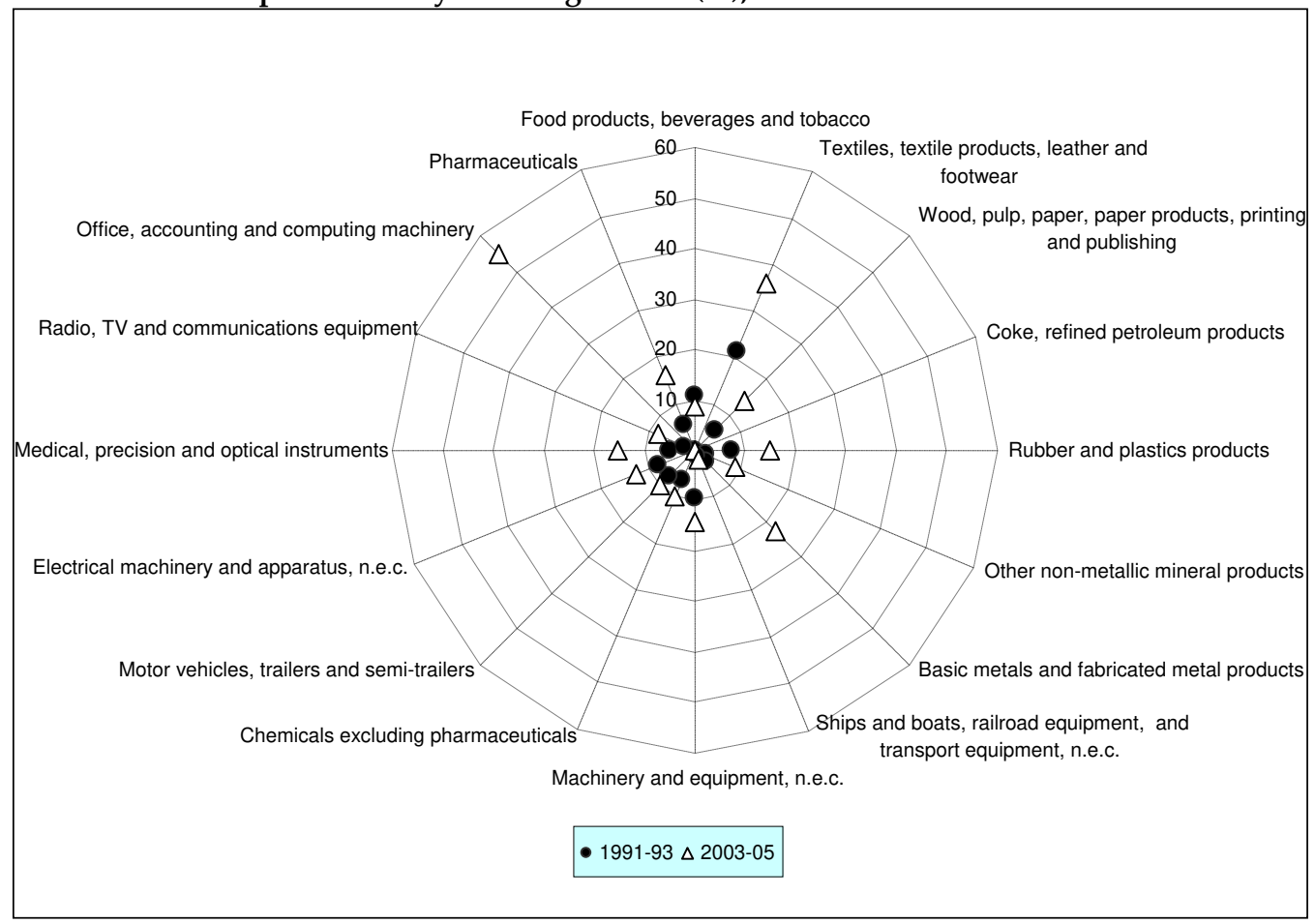

Source: Based on Table-3.

In the literature, it is generally presumed that foreign affiliates are better placed than domestic enterprises in accessing and succeeding in export markets because they have access to information on global markets and parents' global marketing and distribution networks. They are also endowed with high quality intangible assets like technology, brands and skills. Given the overall corporate strategy of the parent firms, foreign firms have these advantages in participating in the global market. In view of this, it is predicted that foreign firms can have higher export intensity than domestic firms. The relative export intensities of sample foreign firms across industries and five time periods have 
been presented in Table-4. It is apparent that foreign firms possess marginally higher export intensity than domestic firms in the Indian manufacturing and for all these subperiods, although domestic firms were able to close the export intensity gap with respect to foreign firms. This suggests that the role of ownership in the export-orientation of firms in total manufacturing has got reduced overtime, which is due to relatively improved performance of domestic firms. However, in many industries foreign firms have higher propensity to exports than their domestic counterparts. In three industries such as Office machinery, Wood including paper and Machinery and equipment, foreign firms' average export intensity is more than double that of domestic firms, more than one-and-a-half times in another three industries (Electrical machinery; Medical, precision and optical instruments; and Chemicals), and about one-and-a-half times in other two industries (Communications equipment, and Textile and leather).

Table-3

Export-orientation of Foreign Affiliates and Domestic Firms in Indian Manufacturing

\begin{tabular}{|c|c|c|c|c|c|c|c|c|c|c|c|}
\hline \multirow{3}{*}{$\begin{array}{c}\text { NIC } \\
98\end{array}$} & \multirow{3}{*}{ Description } & \multicolumn{5}{|c|}{ Export Intensity of Foreign Firms (\%) } & \multicolumn{5}{|c|}{ Export Intensity of Domestic Firms (\%) } \\
\hline & & 1991 & 1994 & 1997 & 2000 & 2003 & 1991 & 1994 & 1997 & 2000 & 2003 \\
\hline & & -93 & -96 & -99 & -02 & -05 & -93 & -96 & -99 & -02 & -05 \\
\hline (1) & (2) & (3) & (4) & (5) & (6) & (7) & (8) & (9) & (10) & (11) & (12) \\
\hline $15-16$ & $\begin{array}{l}\text { Food products, } \\
\text { beverages and } \\
\text { tobacco }\end{array}$ & 10.8 & 11.7 & 11.8 & 8.3 & 8.7 & 6.5 & 11.9 & 7.8 & 9.6 & 8.6 \\
\hline $17-19$ & $\begin{array}{l}\text { Textiles, textile } \\
\text { products, leather } \\
\text { and footwear }\end{array}$ & 21.6 & 35.3 & 37.7 & 34.0 & 36.0 & 12.4 & 21.5 & 26.8 & 26.4 & 28.6 \\
\hline $20-22$ & $\begin{array}{l}\text { Wood, pulp, paper, } \\
\text { paper products, } \\
\text { printing and } \\
\text { publishing }\end{array}$ & 5.6 & 9.2 & 7.4 & 9.2 & 13.8 & 1.4 & 3.4 & 3.3 & 3.0 & 6.1 \\
\hline 23 & $\begin{array}{l}\text { Coke, refined } \\
\text { petroleum products } \\
\text { and nuclear fuel }\end{array}$ & 0.0 & 0.1 & 0.2 & 0.1 & 0.1 & 4.1 & 2.9 & 2.3 & 3.8 & 6.5 \\
\hline 25 & $\begin{array}{l}\text { Rubber and plastics } \\
\text { products }\end{array}$ & 7.1 & 10.0 & 11.3 & 9.5 & 15.0 & 7.6 & 10.1 & 9.9 & 10.0 & 13.5 \\
\hline 26 & $\begin{array}{l}\text { Other non-metallic } \\
\text { mineral products }\end{array}$ & 2.2 & 6.9 & 4.3 & 4.0 & 8.6 & 1.8 & 4.0 & 3.8 & 3.4 & 5.0 \\
\hline $27-28$ & $\begin{array}{l}\text { Basic metals and } \\
\text { fabricated metal } \\
\text { products }\end{array}$ & 3.3 & 15.2 & 11.6 & 13.5 & 22.4 & 5.7 & 8.3 & 9.7 & 10.3 & 15.7 \\
\hline $\begin{array}{c}351+3 \\
52+35 \\
9\end{array}$ & $\begin{array}{l}\text { Ships and boats, } \\
\text { railroad } \\
\text { equipment, and } \\
\text { transport } \\
\text { equipment, n.e.c. }\end{array}$ & 1.2 & 5.2 & 4.5 & 1.2 & 1.9 & 3.1 & 5.0 & 4.0 & 3.2 & 6.7 \\
\hline 29 & $\begin{array}{l}\text { Machinery and } \\
\text { equipment, n.e.c. }\end{array}$ & 9.4 & 8.2 & 9.0 & 12.5 & 14.3 & 3.9 & 4.5 & 4.6 & 5.9 & 7.9 \\
\hline
\end{tabular}




\begin{tabular}{|c|c|c|c|c|c|c|c|c|c|c|c|}
\hline \multirow{2}{*}{$\begin{array}{c}\text { NIC } \\
98\end{array}$} & \multirow[t]{2}{*}{ Description } & \multicolumn{5}{|c|}{ Export Intensity of Foreign Firms (\%) } & \multicolumn{5}{|c|}{ Export Intensity of Domestic Firms (\%) } \\
\hline & & $\begin{array}{c}1991 \\
-93\end{array}$ & $\begin{array}{c}1994 \\
-96\end{array}$ & $\begin{array}{r}1997 \\
-99\end{array}$ & $\begin{array}{c}2000 \\
-02\end{array}$ & $\begin{array}{c}2003 \\
-05\end{array}$ & $\begin{array}{c}1991 \\
-93\end{array}$ & $\begin{array}{c}1994 \\
-96\end{array}$ & $\begin{array}{r}1997 \\
-99\end{array}$ & $\begin{array}{c}2000 \\
-02\end{array}$ & $\begin{array}{c}2003 \\
-05\end{array}$ \\
\hline (1) & (2) & (3) & (4) & (5) & (6) & (7) & (8) & (9) & $(10)$ & (11) & $(12)$ \\
\hline $\begin{array}{c}24 \\
\text { excl. } \\
2423\end{array}$ & $\begin{array}{l}\text { Chemicals } \\
\text { excluding } \\
\text { pharmaceuticals }\end{array}$ & 6.1 & 8.9 & 8.9 & 10.4 & 9.8 & 3.4 & 5.1 & 6.1 & 6.9 & 9.6 \\
\hline 34 & $\begin{array}{l}\text { Motor vehicles, } \\
\text { trailers and semi- } \\
\text { trailers }\end{array}$ & 7.2 & 7.4 & 6.7 & 4.8 & 9.8 & 6.0 & 7.1 & 6.7 & 6.5 & 7.3 \\
\hline 31 & $\begin{array}{l}\text { Electrical } \\
\text { machinery and } \\
\text { apparatus, n.e.c. }\end{array}$ & 8.1 & 11.3 & 11.4 & 13.4 & 12.2 & 4.8 & 5.3 & 7.2 & 7.0 & 9.6 \\
\hline 33 & $\begin{array}{l}\text { Medical, precision } \\
\text { and optical } \\
\text { instruments }\end{array}$ & 5.2 & 7.3 & 9.9 & 9.8 & 15.4 & 2.8 & 5.4 & 6.1 & 6.5 & 9.9 \\
\hline 32 & $\begin{array}{l}\text { Radio, TV and } \\
\text { communications } \\
\text { equipment }\end{array}$ & 2.1 & 2.2 & 6.8 & 6.3 & 8.0 & 2.6 & 3.0 & 3.6 & 2.8 & 4.5 \\
\hline 30 & $\begin{array}{l}\text { Office, accounting } \\
\text { and computing } \\
\text { machinery }\end{array}$ & & 39.3 & 15.9 & 21.6 & 55.3 & 3.4 & 4.5 & 6.4 & 7.1 & 5.0 \\
\hline 2423 & Pharmaceuticals & 5.6 & 7.5 & 9.8 & 10.6 & 15.9 & 13.6 & 19.3 & 23.1 & 25.7 & 35.8 \\
\hline $36-37$ & $\begin{array}{l}\text { Manufacturing, } \\
\text { n.e.c }\end{array}$ & & 92.4 & 93.8 & 99.0 & 99.8 & 77.7 & 72.5 & 64.5 & 64.1 & 71.1 \\
\hline \multicolumn{2}{|c|}{ All Industries (15-37) } & 7.3 & 9.7 & 9.7 & 9.2 & 12.1 & 5.2 & 7.3 & 7.6 & 8.0 & 11.0 \\
\hline
\end{tabular}

Source: Computed based on Prowess database (Release 2), Centre for Monitoring Indian Economy.

Note: Other transport equipments (35) includes 351+352+359 and does not include 353 (Aircraft and spacecraft).

\subsubsection{Industrial Composition of Foreign Firms' Exports}

Exports from foreign firms have also witnessed noticeable changes in their sectoral composition. In 1991-93, a group of four industries stood as the top export contributors with more than 73 per cent of total exports by foreign firms (Table-5). They are Food products with 31.9 per cent, Chemicals with 18 per cent, Motor vehicles with 13.4 per cent and Machinery and equipment with 10 per cent of export share. The emergence of Food products as the largest export contributing sector is led by stronger export orientation of foreign affiliates operating in tea sector like Moran Tea Co. (India) Ltd., Williamson Tea Assam Ltd., Warren Tea Ltd., Assam Co. Ltd., Rossell Industries Ltd., Harrisons Malayalam Ltd., Brooke Bond Lipton India Ltd., Apeejay Tea Ltd. and Goodricke Group Ltd. During 2003-05, foreign affiliates in the Basic metals and fabricated metal products have emerged as the top export contributor with about 23 per cent of total exports by all foreign affiliates in Indian manufacturing. 
Table-4

Relative Export-orientation of Foreign Affiliates

\begin{tabular}{|c|c|c|c|c|c|c|c|}
\hline \multirow[t]{2}{*}{ NIC 98} & \multirow[t]{2}{*}{ Description } & \multicolumn{6}{|c|}{$\begin{array}{l}\text { Export Intensity of Foreign Firms (\%) as a Ratio of } \\
\text { Export Intensity of Domestic Firms (\%) }\end{array}$} \\
\hline & & $\begin{array}{c}1991- \\
93\end{array}$ & $\begin{array}{c}1994- \\
96\end{array}$ & $\begin{array}{c}1997- \\
99\end{array}$ & $\begin{array}{c}2000- \\
02\end{array}$ & $\begin{array}{c}2003- \\
05\end{array}$ & Average \\
\hline $15-16$ & $\begin{array}{l}\text { Food products, beverages and } \\
\text { tobacco }\end{array}$ & 1.67 & 0.98 & 1.51 & 0.87 & 1.00 & 1.21 \\
\hline $17-19$ & $\begin{array}{l}\text { Textiles, textile products, leather } \\
\text { and footwear }\end{array}$ & 1.74 & 1.64 & 1.41 & 1.29 & 1.26 & 1.47 \\
\hline $20-22$ & $\begin{array}{l}\text { Wood, pulp, paper, paper } \\
\text { products, printing and publishing }\end{array}$ & 3.97 & 2.68 & 2.23 & 3.07 & 2.26 & 2.84 \\
\hline 23 & $\begin{array}{l}\text { Coke, refined petroleum products } \\
\text { and nuclear fuel }\end{array}$ & 0.01 & 0.04 & 0.07 & 0.01 & 0.01 & 0.03 \\
\hline 25 & Rubber and plastics products & 0.94 & 0.99 & 1.14 & 0.95 & 1.11 & 1.03 \\
\hline 26 & $\begin{array}{l}\text { Other non-metallic mineral } \\
\text { products }\end{array}$ & 1.21 & 1.70 & 1.12 & 1.15 & 1.74 & 1.38 \\
\hline $27-28$ & $\begin{array}{l}\text { Basic metals and fabricated metal } \\
\text { products }\end{array}$ & 0.58 & 1.83 & 1.19 & 1.31 & 1.43 & 1.27 \\
\hline $\begin{array}{c}351+ \\
352+359\end{array}$ & $\begin{array}{l}\text { Ships and boats, railroad } \\
\text { equipment, and transport } \\
\text { equipment, n.e.c. }\end{array}$ & 0.38 & 1.04 & 1.14 & 0.38 & 0.29 & 0.65 \\
\hline 29 & Machinery and equipment, n.e.c. & 2.40 & 1.83 & 1.98 & 2.12 & 1.82 & 2.03 \\
\hline $\begin{array}{c}24 \text { excl. } \\
2423\end{array}$ & $\begin{array}{l}\text { Chemicals excluding } \\
\text { pharmaceuticals }\end{array}$ & 1.82 & 1.75 & 1.46 & 1.52 & 1.02 & 1.51 \\
\hline 34 & $\begin{array}{l}\text { Motor vehicles, trailers and semi- } \\
\text { trailers }\end{array}$ & 1.19 & 1.05 & 1.00 & 0.73 & 1.35 & 1.06 \\
\hline 31 & $\begin{array}{l}\text { Electrical machinery and } \\
\text { apparatus, n.e.c. }\end{array}$ & 1.69 & 2.14 & 1.57 & 1.92 & 1.27 & 1.72 \\
\hline 33 & $\begin{array}{l}\text { Medical, precision and optical } \\
\text { instruments }\end{array}$ & 1.88 & 1.34 & 1.62 & 1.50 & 1.56 & 1.58 \\
\hline 32 & $\begin{array}{l}\text { Radio, TV and communications } \\
\text { equipment }\end{array}$ & 0.81 & 0.73 & 1.91 & 2.22 & 1.75 & 1.48 \\
\hline 30 & $\begin{array}{l}\text { Office, accounting and computing } \\
\text { machinery }\end{array}$ & 0.00 & 8.72 & 2.50 & 3.05 & 11.09 & 5.07 \\
\hline 2423 & Pharmaceuticals & 0.41 & 0.39 & 0.42 & 0.41 & 0.44 & 0.41 \\
\hline $36-37$ & Manufacturing, n.e.c & 0.00 & 1.27 & 1.46 & 1.54 & 1.40 & 1.13 \\
\hline All & & 1.42 & 1.33 & 1.27 & 1.15 & 1.10 & 1.25 \\
\hline
\end{tabular}

Source: Based on Table-3.

It is well known that with the liberalization of foreign investment regime India has attracted large volume of natural resource seeking FDI, particularly targeted at the steel industry. These foreign firms are motivated to export the extracted raw materials from India for further value-addition in their own home countries. Hence, they have very high 
export intensities and a higher export share in the total exports by all foreign affiliates. Motor vehicles, Chemicals and Food products continue to be important export contributing sectors by foreign affiliates. It is useful to mention that there has been sectoral diversification of export activities of foreign firms during the 1990s. It is indicated by a consistent fall in the share of the top four sectors from 73.5 per cent in 1991-93 to 59.6 per cent in 2000-02, although this share has risen to 63.1 per cent in 200305.

To sum up the discussion in this section, exports of foreign manufacturing firms have increased considerably but their percentage share in total exports from India has remained marginal and more or less stable over time. But this marginal export share of foreign firms in Indian industries has nothing to do with low export-intensity of foreign firms as compared to domestic firms. Foreign firms still have export intensities marginally higher than that of domestic firms but the export-intensity gap has got reduced over time. The marginal export share of foreign firms in Indian manufacturing as compared to other developing countries like China may be due to relatively lower magnitude of FDI that India received. A relatively higher export-intensity of a small number of foreign firms may not improve their share in the host country's exports when the export-intensity of exporting domestic firms is growing relatively faster than foreign firms and a large number of non-exporting domestic firms now taking up export activities.

Table-5

Sectoral Distribution of Foreign Affiliates' Exports from Indian Manufacturing, 1991-2005

\begin{tabular}{|c|c|c|c|c|c|c|}
\hline \multirow[t]{2}{*}{ NIC 98} & \multirow[t]{2}{*}{ Description } & \multicolumn{5}{|c|}{ Percentages } \\
\hline & & 1991-93 & 1994-96 & $1997-99$ & $2000-02$ & 2003-05 \\
\hline (1) & (2) & (3) & (4) & (5) & (6) & (7) \\
\hline $15-16$ & $\begin{array}{l}\text { Food products, beverages } \\
\text { and tobacco }\end{array}$ & 31.87 & 24.29 & 20.41 & 13.57 & 9.71 \\
\hline 17-19 & $\begin{array}{l}\text { Textiles, textile products, } \\
\text { leather and footwear }\end{array}$ & 6.66 & 9.20 & 9.68 & 8.00 & 6.15 \\
\hline $20-22$ & $\begin{array}{l}\text { Wood, pulp, paper, paper } \\
\text { products, printing and } \\
\text { publishing }\end{array}$ & 0.99 & 0.95 & 0.66 & 0.97 & 0.67 \\
\hline 23 & $\begin{array}{l}\text { Coke, refined petroleum } \\
\text { products and nuclear fuel }\end{array}$ & 0.02 & 0.06 & 0.08 & 0.04 & 0.05 \\
\hline 25 & Rubber and plastics products & 2.89 & 3.45 & 2.65 & 1.84 & 1.94 \\
\hline 26 & $\begin{array}{l}\text { Other non-metallic mineral } \\
\text { products }\end{array}$ & 0.39 & 1.06 & 0.63 & 0.52 & 0.95 \\
\hline $27-28$ & $\begin{array}{l}\text { Basic metals and fabricated } \\
\text { metal products }\end{array}$ & 1.86 & 9.92 & 9.45 & 11.62 & 23.40 \\
\hline $351+352$ & Ships and boats, railroad & 0.14 & 0.49 & 0.61 & 0.35 & 0.65 \\
\hline
\end{tabular}




\begin{tabular}{|c|c|c|c|c|c|c|}
\hline \multirow[t]{2}{*}{ NIC 98} & \multirow[t]{2}{*}{ Description } & \multicolumn{5}{|c|}{ Percentages } \\
\hline & & $1991-93$ & $1994-96$ & 1997-99 & $2000-02$ & 2003-05 \\
\hline (1) & (2) & (3) & (4) & (5) & (6) & (7) \\
\hline+359 & $\begin{array}{l}\text { equipment, and transport } \\
\text { equipment, n.e.c. }\end{array}$ & & & & & \\
\hline 29 & $\begin{array}{l}\text { Machinery and equipment, } \\
\text { n.e.c. }\end{array}$ & 9.98 & 6.31 & 6.34 & 8.04 & 6.51 \\
\hline $\begin{array}{c}24 \text { excl. } \\
2423\end{array}$ & $\begin{array}{l}\text { Chemicals excluding } \\
\text { pharmaceuticals }\end{array}$ & 18.29 & 17.32 & 20.62 & 25.15 & 14.49 \\
\hline 34 & $\begin{array}{l}\text { Motor vehicles, trailers and } \\
\text { semi-trailers }\end{array}$ & 13.36 & 12.61 & 12.17 & 9.61 & 15.82 \\
\hline 31 & $\begin{array}{l}\text { Electrical machinery and } \\
\text { apparatus, n.e.c. }\end{array}$ & 6.81 & 6.80 & 5.92 & 7.26 & 4.50 \\
\hline 33 & $\begin{array}{l}\text { Medical, precision and } \\
\text { optical instruments }\end{array}$ & 0.32 & 0.54 & 0.70 & 0.75 & 0.67 \\
\hline 32 & $\begin{array}{l}\text { Radio, TV and } \\
\text { communications equipment }\end{array}$ & 0.77 & 0.66 & 2.21 & 1.72 & 1.49 \\
\hline 30 & $\begin{array}{l}\text { Office, accounting and } \\
\text { computing machinery }\end{array}$ & 0.00 & 0.43 & 0.76 & 3.11 & 5.24 \\
\hline 2423 & Pharmaceuticals & 5.64 & 4.89 & 5.87 & 5.97 & 6.30 \\
\hline $36-37$ & Manufacturing, n.e.c & 0.00 & 1.02 & 1.26 & 1.49 & 1.46 \\
\hline $15-37$ & All Industries & 100 & 100 & 100 & 100 & 100 \\
\hline \multicolumn{7}{|c|}{ Mimeo: Four Industries' concentration ratio } \\
\hline \multicolumn{2}{|c|}{ Share of top four industries } & 73.50 & 64.14 & 62.87 & 59.95 & 63.42 \\
\hline
\end{tabular}

\section{Transformation of Market-seeking FDI into Export-oriented FDI: Main Hypotheses}

In the literature, a horizontal FDI project is generally classified as market-seeking or export-oriented depending on its overall market orientation ${ }^{3}$. If the FDI project is geared mainly to supply the host country markets, it is termed market-seeking. The main attractive factor for such an FDI project is the size and income growth of host countries. On the contrary, an FDI project is labelled export-oriented if it is primarily motivated to use the host country as a platform for exporting to the global or regional markets. Exportoriented FDI is also known as efficiency-seeking FDI as it is driven by the benefits from location-specific cost advantages like low wage costs, low inflation, undervalued exchange rates and availability of quality infrastructure in transportation, telecommunications and energy.

3 When an investing firm undertakes similar business activity abroad as pursued in the home country it is known as horizontal FDI. In the case of vertical FDI, production abroad does not replicate the activities undertaken at home country. 
Although the above distinction is categorical in a conceptual sense, in real market situations there are several factors that can encourage the market-seeking FDI to diversify into export activities and thus the distinction between market-seeking and export-oriented FDI may be blurred. It may be true that accessing the host country market was the initial objective of a market-seeking FDI project as can be observed in the case of a tariff-jumping FDI but that objective may diversify to include export markets depending upon several factors related to market condition in host location and government policies. For a realistic example, one can think of the Indian economy where most of the FDI projects attracted prior to the 1990s are market-seeking in nature. They are basically tariff-jumping FDI wanting to gain access to the large size of local market sheltered by the strong import protection regime followed by India. Therefore, it is not surprising that foreign affiliates have contributed merely 3 per cent of total industrial exports from India in 1985 and 1991(UNCTAD 2002, p. 154).

The first set of factors that can lead this market-seeking FDI to exports is related to locational advantages. If the host country is able to improve its locational advantages significantly vis-à-vis home country of the FDI projects and other competing locations in terms of providing relatively good infrastructure, availability of skills, facilitating institutions, etc., then this could induce foreign firms to rethink their market strategy and may influence them to use the host country as an export platform. The second set of factors that can influence exporting decision of FDI is related to the level of host country market, local competition and sectoral characteristics. A large and growing domestic market may generate incentives for foreign affiliates to scale down their plans for exportoriented manufacturing and thus slow down switching their sales from the local to export markets. The increased competitive strength in domestic firms due to firm-specific productivity improvement, technological efforts, brand-building exercise, and increased skill bundle can reduce domestic market share of foreign affiliates and may compel them to look for exporting, especially when they are least interested in quitting a large-sized and growing market. The third set of factors relates to the shift in the policy regime. If the economy significantly liberalizes its policy regime by increasing openness to FDI, removing non-tariff barriers and lowering tariffs, and instituting new measures of export promotion, then this policy shift may also push market-seeking FDI into export activities. As far as the present study is concerned we will confine our attention to the last two sets of factors and will be specifically interested in examining the following hypotheses:

\section{H1. Host Country Market and Foreign Firms' Export-orientation}

Evidence from several cross-country studies on the determinants of FDI inflows indicate that the size and growth of the host economy are two important factors that positively 
attract FDI projects (see, e.g., UNCTAD 1993). Large economies represent large demand potentials and thus pull foreign firms to set up their production base with the benefits of attaining economies of scale and lower transaction costs. In this view a large domestic market and its high growth rates may affect the export-orientation of foreign firms by keeping them more focused on host market. However, once foreign firms set up their production facilities and later find that the host country has limited market potentials than they expected, it may force them to change their market strategy from domestic to export market. The study done by ECLAC (2004) on Brazil found that increased competitive pressure from imports and the contraction of the domestic market in the late 1990s have forced foreign firms in Brazil to export a larger proportion of their output. The empirical evidence from China also suggests a similar experience of foreign affiliates. ${ }^{4}$ In the present study domestic market is represented by the total domestic requirement consisting of domestic sales of the industry plus import demand. Thus, we have postulated a negative relationship between export-intensity of foreign firms, size and growth of domestic market.

\section{H2. Host Country Competition and Foreign Firms' Export-orientation}

The literature emphasizes that the developmental role of FDI in host countries depends critically on the level of competitive capabilities of local firms. The technological and skill capabilities of domestic firms not only ensure that the multinational firms increase their technology transfers to host country, but also that the host country benefits from absorbing knowledge spillovers generated by foreign affiliates. Blomstrom et al. (1994), for Mexico manufacturing found that local competition had forced multinational firms to increase the technology transfers to their Mexican affiliates. Several studies on FDI spillovers indicate that without a sufficient level of absorptive capabilities (as measured by R\&D investments and skill) host countries may fail to benefit from spillovers from FDI (see, Saggi 1999, for a survey).

The study contends that the role of domestic competition is important not only for benefiting from FDI spillovers, but also for influencing the export strategies of foreign affiliates. The main channel through which local competition can act on the exportorientation of foreign firms is through its effect on the domestic market share of foreign affiliates. An increasing level of local competition due to growing firm-specific assets of

4 Many foreign firms like the US ball-bearing manufacturer, Timken, came to China with the initial assumption of serving a large local market. However, low volume and slow automotive demand in China following the Asian financial crisis of 1997-98 have forced Timken to look for export market and now 70 per cent of its production in China is being exported (Economist Intelligence Unit, 2004). 
local firms like technology, skills, and brand names can negatively affect the market share of foreign affiliates. The reduced market share, in turn, can significantly reduce the profit margins earned from the host market. This may unleash two opposing forces acting on the export-intensity of foreign affiliates. First, foreign firms faced with eroding market share and profit in a large market are likely to respond by increasing technology transfer to their affiliates so as so retain and increase their domestic market position. In this situation, growing domestic competition is expected to have negative impact on export activities of foreign firms. Second, if local competition grows much stronger even after foreign affiliates receive higher technology support from their parent companies and if they are not interested to exit from a large market, then they can even diversify their market segment to serve regional markets. Thus, the theoretical prediction on the nature of overall impact of local competition on the export-orientation of foreign firms depends upon the relative strengths of these opposing forces and is ambiguous. In the study the local competition is measured by the percentage increase in the domestic firms' market share.

\section{H3. Domestic Firms' Export Performance and Foreign Firms' Export- orientation}

Most often in the literature, inward FDI has been claimed as a positive factor for developing country firms for breaking entry-barriers into export markets. Several studies have appeared to examine the export-spillovers effect of FDI on domestic firms. It is apparent that the possibility for such effects is higher only when FDI projects are basically export-oriented and not domestic market-seeking. In the case of foreign investment focusing only on host market, the export-spillovers effect works in reverse direction. A higher and increasing export orientation of domestic firms in an industry suggests that these firms are doing well in the international markets and that the host country in fact possesses a strong competitive advantage for exporting. This may have a demonstration effect on foreign firms, hitherto primarily supplying to the local market, to explore the possibility and potential for exporting. On the contrary, poor exportorientation of domestic firms in an industry is a signal to foreign firms that the host country does not provide potential for exporting in that industry. Other things being equal, we predict that the export-orientation of foreign affiliates is positively related to the export-orientation of domestic firms across industries.

\section{H4. Import Competition and Foreign Firms' Export-orientation}

The higher the level of import competition an industry faces, the existing foreign affiliates as well as domestic firms may be forced to look for export markets. Several studies have found that increased import competition serves to lower the mark-up or 
profit margins of industries (Roberts and Tybout 1996, Currie and Harrison 1997, Krishna and Mitra 1998). The lower profit margins can force industries/firms (both foreign and domestic) to improve productivity (e.g., MacDonald 1994) and also to seek additional markets. The market-expansion effect of import competition can be expected to be strong in the case of economies like India, which are implementing measures of trade liberalization after pursuing an import protection policy for a long period. The tariffjumping FDI which came into these countries during the protected period may be facing intensified import competition following the implementation of economic liberalization and this can be predicted to bring a positive change in their export-orientation.

\section{H5. Host Country Policy Regime and Foreign Firms' Export-orientation}

It is well recognized in the literature that a proactive, strategic, and export-oriented policy regime has been instrumental in the case of countries which have made large gains in international market shares such as China, South Korea, Costa Rica, Hungary, Ireland and Mexico (UNCTAD 2002). Under an export-oriented policy regime, enterprise-level competitiveness is much stronger as international competition forces domestic firms to continuously upgrade their technological capabilities, speed up learning processes, improve quality and to exploit size and scale advantages (Bhagwati and Krueger 1974). On the contrary, the import protection regime generally hurts competitiveness by assuring a protected market and also it generates biases against export activities. The high tariff and non-tariff barriers induce tariff-jumping FDI to serve the local market. Therefore, when a country shifts from the import protection regime into an open regime, this can change market orientation of firms both foreign and domestic.

The export-orientation of foreign affiliates will change following the regime shift because of three factors. First, the emergence of liberal policy regime towards trade, FDI, industry and technology can attract export-oriented FDI (Aggarwal 2002). Second, the removal of the anti-export biases of the earlier protected regime can induce the tariff-jumping FDI to consider the option of exporting under the liberal policy regime. Third, the exportorientation of foreign affiliates can increase because the effectiveness of government export promotion schemes like establishing export processing zones (EPZs), special economic zones (SEZs) and fiscal incentives increases under the liberal trade regime.

Following the standard practice in the literature, the study has used a regime-shiftdummy to capture the impact of new regime on foreign firms' export-orientation. The full-scale economic reforms in India were launched in 1991 putting in place a most outward oriented development policy and displacing the decades-old import substituting-inward looking growth strategy. Since then India has expanded and 
strengthend the process of economic liberalization over time to new areas. While the policy break took place in 1991, its impact on economic agent can be felt with a lag. So which year can be taken as a policy cut-off point has to be determined. For this purpose, we have run the regression individually for three regime shift dummies representing 1993, 1994 and 1995 and have chosen 1993 as the effective policy break year as far as export-orientation of foreign affiliates are concerned ${ }^{5}$. It is postulated that the dummy variable, taking zero up to 1993 and unity for post-1993 years, shall have a positive sign to signify that export-intensity under the new regime is higher than that under the old regime.

In addition to the above-mentioned variables, there are other sector-specific observable factors that can cause the export-orientation of foreign affiliates to vary over industries. In fact, the export structure of selected countries like China, Costa Rica, Hungary, Mexico and South Korea that have achieved strong global competitiveness between 1985 and 2000, suggests that foreign affiliates, through equity and non-equity links, have contributed remarkably in high and medium technology-intensive products than in low technology-intensive products (UNCTAD 2002, pp. 161-180). Partly, the inter-industry differentials in foreign affiliates' export intensity might have been due to government policies. For example, the host country policy used to permit FDI only into technologyintensive industries (not in consumer goods and labour-intensive industries), and also permission was contingent upon an export obligation. Besides sectoral dummies, interindustry differences in the technology intensity, extent of product differentiation activities, scale (measured by average firm size) and average firm age are included as controlling factors for sectoral characteristics.

Now, specifying the response variable, export intensity of foreign firms, as a function of above discussed independent variables we obtain our empirical model:

$$
\begin{aligned}
\text { FEXINT }_{i t}=\mu_{i} & +\beta_{1} D M K T_{i t}+\beta_{2} G D M K T_{i t}+\beta_{3} \text { DCOM }_{i t}+\beta_{4} \text { DEXINT }_{i t}+\beta_{5} \operatorname{IMCOM}_{i t} \quad \ldots \ldots 1 \\
& +\beta_{6} \text { RDINT }_{i t}+\beta_{7} A D V I N T_{i t}+\beta_{8} \operatorname{SIZE}_{i t}+\beta_{9} A G E_{i t}+\beta_{10} P S D U M+e_{i t}
\end{aligned}
$$

Where; FEXINT it is the export-intensity of foreign firms. It is measured by total exports as a percentage of total sales of foreign firms in ith industry for th year.

5 These regime shift dummies have come out with robust $z$ statistic value of $11.4,1.95$ and -0.79 respectively. Clearly, the year 1993 with highest robust $\mathrm{z}$ statistics has been taken as the preferred regime shift dummy. 
$\mathrm{DMKT}_{\text {it }}$ is the size of domestic market for ith industry's product and for th year. It is derived as a sum of domestic sales of the ith industry (total sales minus exports) and imports of ith product.

GDMKT $_{i t}$ is the annual growth rate of the domestic market for ith industry in tth year.

DCOMit is the domestic competition proxied by the percentage share of domestic firms in domestic sales (total sales minus exports) of ith industry in th year.

DEXINT $_{\text {it }}$ is the export-intensity of domestic firms in ith industry and in tth year. It is equal to the percentage share of exports in total sales of domestic firms in ith industry and th year.

IMCOMit is the import competition represented by the total imports as a percentage share of total value-added of ith industry in th year.

$R_{D I N T}$ it is the R\&D intensity, calculated as the percentage of total R\&D expenditures in total sales of ith industry in th year.

ADVINT $_{i t}$ is the advertising intensity proxied by the total advertising expenses as a percentage of total sales of ith industry in tth year.

SIZEit is the average firm size in ith industry in th year.

AGEit is the average firm age in ith industry in tth year.

PSDUM is the policy-shift-dummy, takes 1 for new policy regime (1994 onwards) and 0 for the old policy regime (1991-93).

$\mu_{\mathrm{i}}$ is a time-invariant unobserved permanent industry-specific effect.

eit represents a time-varying transitory industry-specific un-observables (i.e. random errors).

\section{Data Sources and Methodology of Estimations}

\subsection{Data Sources}

The model has been estimated for a panel dataset of 14 Indian industries for 14 years over 1992-2005. This dataset has been constructed mainly from two sources of the Centre for Monitoring Indian Economy, namely Prowess Database (Release 2.5) and India 
Trades (Version 2.0). From the Prowess Database we have abstracted firm-level financial information covering sales, exports, equity share of foreign promoters, etc. of 5034 Indian manufacturing firms. Using the detailed product description, these firms are grouped into 18 industries based on National Industrial Classification (NIC) 1998 and divided into foreign and domestic firms across these industries based on 10 per cent equity criterion. In classifying the foreign firms a total of 38 firms as shown in Appendix Table-A1 were included in the list of foreign firms even though their foreign ownership participation was reported as zero or less than 10 per cent because they were part of foreign groups operating in Indian manufacturing.

It should be noted that Prowess tends to put zero when information on a variable like foreign promoters' share is not available. Of the 18 industries, four industries such as ships and boats, railroad equipment, and transport equipment, n.e.c.; office, accounting and computing machinery; manufacturing, n.e.c; and diversified industrial group were dropped from the sample due to limited number of foreign firms in these industries. Finally, the sample contains a total of 4975 firms, of which 522 are foreign owned (see, Appendix Table-A2 for industrial distribution of the number of foreign firms in the sample). After these industrial and ownership classification of firms, we have generated required industry-wise aggregate for various relevant variables of our interest. All the industry-wise variables, except IMCOM, have been generated from the above sample and for few variables in combination with the industry-wise imports data obtained from the following source. The data on India's manufactured imports at the 4-digit of the harmonized system (HS) codes, 1996, has been obtained from India Trades database. Later using a concordance developed in-house between HS 1996 and NIC 1998, we have mapped them into NIC groups. Deflating these industry-wise imports by the valueadded generated from the Prowess database, the variable IMCOM has been constructed.

\subsection{Methods of Estimation}

Given the panel structure of our dataset, we have examined the standard panel data techniques like fixed and random effects to estimate casual parameters of the model (1). The most important advantage of such models is that they recognize industry-specific heterogeneities induced by their unobservable time-invariant permanent characteristics ( $\mu_{\mathrm{i}}$ in Model 1) and, thus, provide robust casual inferences. When these $\mu_{\mathrm{i}}$ are correlated with the independent variables, fixed effects estimation provides unbiased, consistent and efficient estimators and when there is no such correlation, random effects estimation is most efficient. Empirically, the choice between these two models is decided by adopting the Hausman specification test (1978). The result from this test indicates that a fixed effect model produces a different set of estimators than random-effects and that the 
industry-effects are correlated with the regressors in the model ${ }^{6}$. In this case application of fixed effects is more appropriate than random effects. We have used the statistical package, STATA, to conduct Hausman test and other empirical analysis.

After an examination of collinearity among independent variables it is found that one industry characteristic, average firm size (SIZEit), is highly correlated with domestic market size (DMKTit) and, hence, we decided to drop this particular control variable from the estimation. Re-estimation of the variance inflating factor (VIF) suggests that the variable domestic competition (DCOMit) is still highly collinear with other independent variables as reflected by the fact that VIF is equal to 18 . To address this problem, we have normalized the domestic competition variable by the number of domestic firms and, thus, the variable now measures per-firm market share of domestic enterprises. Collinearity results obtained after this transformation are reported in Appendix TableA3. It can be seen that VIF of DCOMit has fallen to 10.5 and is about the cut-off point prescribed by the thumb rule that VIF should not be more than 10. The VIF of another independent variable, namely export intensity of domestic firms, DEXINT, is 13.5 and is not a large deviation from the rule of thumb. However, in view of the slightly higher VIF caution needs to be exercised while interpreting the results.

Besides addressing the problem of collinearity and panel-specific heterogeneities in a fixed-effects method, the success of drawing acceptable casual inferences depends largely on obtaining a valid standard error. This calls for testing and obtaining standard errors that are consistent to various problematic error structures like heteroscedastic, serial and contemporaneous correlated errors. STATA implemented the Greene's modified Wald test for panel-specific heteroscedasticity in the residuals of a fixed effect regression model (Greene 2000, p. 598). The null-hypothesis of homoscedasticity has been rejected even at 1 per cent level of statistical significance suggesting that error variances are specific to industries ${ }^{7}$. The Wooldridge test for autocorrelation in panel data has also strongly rejected the null hypothesis of no first-order autocorrelation in most of the industries ${ }^{8}$ (Wooldridge 2002). Following Greene (2000, p. 601), STATA also performs the BreuschPagan statistic for contemporaneous independence in the residuals of a fixed effect

6 Hausman specification test: Ho: difference in coefficients not systematic. The estimated chi2 (8) $=46.23$ and its Prob $>$ chi $2=0.0000$.

7 Modified Wald test for group-wise heteroskedasticity in fixed effect regression model: Ho: $\sigma \mathrm{i} 2=$ $\sigma 2$ for all i. chi2 $(14)=804.30$, Prob $>$ chi2 $=0.0000$.

8 Wooldridge test for autocorrelation: Ho: no first-order autocorrelation. $F(1,13)=27.882$. Prob $>F$ $=0.0001$. 
regression ${ }^{9}$. The chi-square statistic has come out with 1 per cent significance, indicating that the errors are not independent over industries. In view of above problems, we have adopted two types of estimation, one is the fixed effects estimation with Huber-White robust standard errors consistent for not identically distributed and within panel serially correlated errors and the other is the feasible generalized least squares (GLS) estimation with standard errors robust to heteroscedastic error structures with cross-sectional correlation and within panels first-order autocorrelation ${ }^{10}$. In the case of GLS we also have provided controls for panel-specific heterogeneity represented by industry-specific effects.

\subsection{Results and Inferences}

In Table-6 we have summarized two sets of results from fixed effects and GLS regressions for the model (1) excluding the policy shift dummy. The very high values of $\mathrm{F}$ and Wald Chi-square statistics for the overall model significance reject the hypothesis that none of the independent variables significantly affect the export-intensity of foreign firms. Thus, both the estimated models are significant and in the case of fixed effects, the fitted model explains about 93 per cent of the variation in the response variable ${ }^{11}$. The performance of individual explanatory variables is presented below.

DMKT capturing the size of the domestic market emerges with a negative sign for both fixed effect and GLS estimation and is statistically significant in the latter estimation at 1 per cent level. This supports our prediction that large size of the domestic market is more attractive for foreign firms and tends to slow down the diversification process of their focus towards export market. However, GDMKT measuring the fluctuations in the size of the domestic market has come up with statistically insignificant effect on foreign firms' export-orientation. Therefore, while the size of the domestic market is an important factor in explaining the export-intensity of foreign firms, its fluctuation is not so important. Since export activities involve substantial sunk costs and is path-dependent, it

9 Breusch-Pagan LM test of cross-sectional independence: $\operatorname{chi} 2(91)=133.884$, Prob $>$ chi2 $=0.0023$

10 In STATA, the command areg y x1 x2 ..., absorb (panel code) robust cluster, would estimate a linear fixed effects model with robust estimators which are consistent with the problems of conditional heteroscedasticity as well as arbitrary within correlation including autocorrelation of any form. xtgee, y x1 x2 ....panel dummies, $\mathrm{p}(\mathrm{c}) \mathrm{c}(\mathrm{ar} 1)$ would provide feasible generalized least squares estimates and standard errors consistent with heteroscedasticity with crosssectional and within panel correlated errors.

11 In the case of GLS, the R-squared is not a useful statistic since it fails to break down the total sum of squares into the explained sum of squares and the residual sum of squares. 
is quite reasonable that such activities are independent of yearly fluctuations in the size of the domestic market.

DCOM measuring domestic competition has come up with a statistically significant coefficient and a negative sign in both the estimations. The result suggests that foreign firms in Indian industries when faced with intensifying domestic competition have put more focus on the domestic market. Setbacks in market share in a fast growing and large economy due to domestic competition seems to have made foreign firms more aggressive in the domestic market rather than in export activities.

The export-intensity of domestic firms, DEXINT, possesses a strong positive effect on export intensity of foreign affiliates in fixed effect as well as GLS estimation. This empirical finding broadly corroborates the predicted positive relationship between DEXINT and foreign firms' export-orientation. Therefore, significant level of domestic export activities in a sector is an important factor for export involvement by foreign affiliates in that sector. Higher export activities by domestic enterprises tend to have a demonstration effect on the behaviour of foreign affiliates and effectively induce them to exploit the rising export potential of the host country.

IMCOM has a positive sign and achieves a strong statistical significance level at 1 per cent and in both the estimations. Hence, import competition, on account of dismantling of the protected regime, seems to have prompted foreign affiliates in Indian manufacturing to consider exporting as a strategy to meet the new competitive situations. Foreign affiliates previously operating in a protected market, now find that an open domestic market is not enough to maintain their production at the full capacity and scale and thus additional market through exporting is needed. Hence, import competition may be forcing many tariff-jumping foreign firms to consider a greater extent of export activities.

All the three industry-specific characteristics, namely industry R\&D intensity (RDINT), industry advertising intensity (ADVINT) and industry level average firm age (AGE) have all come up with statistically significant effects. RDINT and ADVINT have significant negative coefficients, suggesting that foreign affiliates in higher R\&D- and advertisingintensive industries have lower propensities to exports. AGE has a positively significant sign indicating that foreign affiliates' export-orientation is positively related to the average firm age in Indian industries. 
Table-6

Determinants of Foreign Firms' Export-orientation

\begin{tabular}{|c|c|c|}
\hline \multirow{2}{*}{\multicolumn{3}{|c|}{ Dependent Variable: Export-intensity of All Foreign Firms }} \\
\hline & & \\
\hline \multirow[t]{2}{*}{ Independent Variables } & Fixed Effects Estimation & FGLS Estimation \\
\hline & $\begin{array}{l}\text { Coefficient } \\
(t \text { value })\end{array}$ & $\begin{array}{l}\text { Coefficient } \\
\text { (z value })\end{array}$ \\
\hline (1) & $(2)$ & (3) \\
\hline DMKT & $\begin{array}{c}-0.000007 \\
(1.09)\end{array}$ & $\begin{array}{c}-0.000009^{* * *} \\
(13.61)\end{array}$ \\
\hline GDMKT & $\begin{array}{c}0.010888 \\
(0.65)\end{array}$ & $\begin{array}{c}-0.000308 \\
(0.27)\end{array}$ \\
\hline DCOM & $\begin{array}{l}-0.576563^{* *} \\
(2.01)\end{array}$ & $\begin{array}{c}-0.332244^{* * *} \\
(14.35)\end{array}$ \\
\hline DEXINT & $\begin{array}{l}0.685383^{* * *} \\
\quad(5.79)\end{array}$ & $\begin{array}{l}0.625295^{* * *} \\
\quad(83.09)\end{array}$ \\
\hline IMCOM & $\begin{array}{c}0.003818^{* * *} \\
(3.86)\end{array}$ & $\begin{array}{l}0.002920^{* * *} \\
(11.74)\end{array}$ \\
\hline RDINT & $\begin{array}{c}-1.011445^{*} \\
(1.74) \\
\end{array}$ & $\begin{array}{c}-0.562487^{* * *} \\
(13.94)\end{array}$ \\
\hline ADVINT & $\begin{array}{c}-0.983600^{* *} \\
(2.15) \\
\end{array}$ & $\begin{array}{c}-0.918459^{* * *} \\
(18.72)\end{array}$ \\
\hline AGE & $\begin{array}{l}0.156903^{* *} \\
(1.98)\end{array}$ & $\begin{array}{c}0.230426^{* * *} \\
(14.49)\end{array}$ \\
\hline Constant & $\begin{array}{c}2.510447 \\
(1.30)\end{array}$ & - \\
\hline R-squared & 0.93 & - \\
\hline $\mathrm{F}(7,174)$ & 77.05 & - \\
\hline Prob $>$ F & 0.0000 & - \\
\hline Wald chi2(21) & - & 74289.67 \\
\hline Prob > chi2 & - & 0.0000 \\
\hline Observations & 196 & 196 \\
\hline Number of industries & 14 & 14 \\
\hline Time periods & 14 & 14 \\
\hline \multicolumn{3}{|l|}{ Memorandum } \\
\hline Controls for 'industry-effects' & Yes & Yes \\
\hline $\begin{array}{l}\text { Standard errors robust to panel- } \\
\text { specific heteroscedasticity }\end{array}$ & Yes & Yes \\
\hline $\begin{array}{l}\text { Standard errors robust to panel auto- } \\
\text { correlation }\end{array}$ & Yes & Yes \\
\hline $\begin{array}{l}\text { Standard errors robust to } \\
\text { contemporaneous correlation }\end{array}$ & No & Yes \\
\hline
\end{tabular}

Note: Absolute value of robust $\mathrm{t}$ and $\mathrm{Z}$ statistics in parentheses; ${ }^{*}$ significant at $10 \%$; ${ }^{* *}$ significant at $5 \%{ }^{* * *}$ significant at $1 \%$. 


\subsection{Impact of the New Policy Regime}

To investigate the impact of the new policy regime followed since 1991 on the exportintensity of foreign firms, we have included a policy shift dummy in the model. This dummy variable takes value 0 for 1992 and 1993 and 1 for all years after 1993. The inclusion of PSDUM into the model led to an increase in the multi-collinearity problem among independent variables (Appendix Table-A4). The mean VIF for the model has increased from 5.88 (when PSDUM was not included) to 6.34 (after PSDUM is included); but this level is well within the acceptable limit. However, the VIF values of two independent variables suffering from multi-collinearity problems, namely DCOM and DEXINT have to be seen carefully. While VIF of DCOM has increased from 10.5 to 12.7 that of DEXINT has remained more or less unchanged. Hence, the finding on DCOM is to be viewed subject to this increased collinearity magnitude. The Hausman test suggest that fixed effects estimation is more efficient than random effects ${ }^{12}$ and other tests reveals that errors are serially ${ }^{13}$ and contemporaneously correlated ${ }^{14}$ and their variances vary across industries ${ }^{15}$. To address these problems, we are continuing to adopt the GLS regression besides furnishing results from fixed effects with standard errors robust to industry-wise heteroscedasticity and auto-correlated errors.

Table-7 summarizes results from both fixed effects and GLS regressions explaining the export-orientation of foreign affiliates in Indian industries. The policy shift variable, PSDUM, has consistently positive impact over estimations and is statistically significant in the case of GLS estimation. This suggests that export-orientation of foreign affiliates have improved in the new policy regime as compared to old inward-looking policy phase. It appears that export propensity of foreign affiliates have responded positively to a liberal trade and investment regime that has removed anti-export bias and has set up numerous export processing and special economic zones increasing necessary infrastructure for possible exports activities. Among the existing variables, except DCOM, all others continued to have same performance as in estimations without including of PSDUM. DCOM has now come up with an insignificant coefficient. Therefore, the performance of DCOM is sensitive to inclusion/exclusion of PDUM and

12 Hausman specification test: Ho: difference in coefficients not systematic. The estimated chi2 (9) $=239.06$ and its Prob $>$ chi $2=0.0000$.

13 Wooldridge test for autocorrelation: Ho: no first-order autocorrelation. $F(1,13)=8.605$, Prob $>$ F $=0.0116$.

14 Breusch-Pagan LM test of cross-sectional independence: chi2 (91) = 126.460, Pr=0.0083.

15 Modified Wald test for group-wise heteroskedasticity in fixed effect regression model: Ho: $\sigma i 2=$ б2for all i. chi2 $(14)=302.95$, Prob $>$ chi $2=0.0000$. 
may be due to the problem of collinearity that DCOM has with other independent variables.

Table-7

New Policy Regime and Foreign Firms' Export-orientation

\begin{tabular}{|c|c|c|}
\hline \multicolumn{3}{|c|}{ Dependent Variable: Export-intensity of All Foreign Firms } \\
\hline Independent Variables & $\begin{array}{l}\text { Fixed Effects Estimation } \\
\text { Coefficient (t value) }\end{array}$ & $\begin{array}{l}\text { FGLS Estimation } \\
\text { Coefficient ( } \mathrm{z} \text { value) }\end{array}$ \\
\hline (1) & (2) & (3) \\
\hline DMKT & $\begin{array}{c}-0.000007 \\
(0.93)\end{array}$ & $\begin{array}{c}-0.000009^{* * *} \\
(12.85)\end{array}$ \\
\hline GDMKT & $\begin{array}{c}0.006381 \\
(0.41)\end{array}$ & $\begin{array}{c}0.000950 \\
(0.73)\end{array}$ \\
\hline NDCOM & $\begin{array}{c}-0.190790 \\
(0.55)\end{array}$ & $\begin{array}{c}0.013039 \\
(0.49)\end{array}$ \\
\hline DEXPOINT & $\begin{array}{l}0.660642^{* * *} \\
(6.18)\end{array}$ & $\begin{array}{l}0.599152^{* * *} \\
(48.75)\end{array}$ \\
\hline IMCOM & $\begin{array}{l}0.003885^{* * *} \\
(3.69)\end{array}$ & $\begin{array}{l}0.002855^{* * *} \\
(10.57)\end{array}$ \\
\hline PSDUM & $\begin{array}{c}1.257565 \\
(1.43)\end{array}$ & $\begin{array}{c}1.043070^{* * *} \\
(11.40)\end{array}$ \\
\hline RDINT & $\begin{array}{c}-0.987712^{*} \\
(1.78)\end{array}$ & $\begin{array}{l}-0.545648^{* * *} \\
(8.72)\end{array}$ \\
\hline ADVINT & $\begin{array}{l}-1.220788^{* *} \\
(2.35)\end{array}$ & $\begin{array}{l}-0.966005^{* * *} \\
(12.95)\end{array}$ \\
\hline AGE & $\begin{array}{c}0.108916 \\
(1.15)\end{array}$ & $\begin{array}{l}0.207506^{* * *} \\
(11.49)\end{array}$ \\
\hline Constant & $\begin{array}{c}2.552906 \\
(1.30)\end{array}$ & \\
\hline R-squared & 0.93 & \\
\hline $\mathrm{F}(8,173)$ & 48.9 & \\
\hline Prob $>$ F & 0.0000 & \\
\hline Wald chi2(22) & & 70084.18 \\
\hline Prob > chi2 & & 0.0000 \\
\hline Observations & 196 & 196 \\
\hline Number of industries & 14 & 14 \\
\hline Time periods & 14 & 14 \\
\hline \multicolumn{3}{|l|}{ Memorandum } \\
\hline Controls for 'industry-effects' & Yes & Yes \\
\hline $\begin{array}{l}\text { Standard errors robust to panel-specific } \\
\text { heteroscedasticity }\end{array}$ & Yes & Yes \\
\hline Standard errors robust to panel auto-correlation & Yes & Yes \\
\hline $\begin{array}{l}\text { Standard errors robust to contemporaneous } \\
\text { correlation }\end{array}$ & No & Yes \\
\hline
\end{tabular}

Note: Absolute value of robust $\mathrm{t}$ and $\mathrm{Z}$ statistics in parenthesis; ${ }^{*}$ significant at $10 \%$; ${ }^{*}$ significant at $5 \%{ }^{* * *}$ significant at $1 \%$. 


\section{Conclusion and Policy Implications}

In this paper we have made an exploratory attempt to estimate the export contribution of foreign affiliates in Indian industries and analyze factors that determine the propensity of foreign affiliates to undertake exports activities. As far as volume of exports by foreign affiliates is concerned, they have grown significantly across industries with rising exportintensities. However, their share in the total manufacturing export ranges from 7 to 9 per cent during 1991-2005 because of relatively higher export performance of their domestic counterparts and relatively smaller number of foreign firms.

Appropriate analytical framework was developed based on theoretical understandings and previous empirical studies done on India as well as other countries to examine factors determining the export-orientation of foreign manufacturing affiliates in India. The empirical verification of the framework for a group of 14 industries during 19922005 identifies certain tendencies of foreign affiliates which entail discrete policy implications. These factors, tendencies and likely policy implications are summarized below.

i. Foreign affiliates' export propensities are more sensitive to the size of the domestic market than fluctuations in the size. These firms are strongly lured by the large size of the host market and hence have less incentive to explore the export potentials of the host country. In other words, India is suffering from a negative bias from a large domestic market on export-intensity of foreign affiliates. However, the Chinese experience shows that large size of the domestic market may not discourage foreign firms from using a host country as a platform for exports production once the host country has a proactive policy regime. China has been successful in bargaining its large market to force foreign firms to transfer technology as a condition of entry and also offered extraordinary concessions (Shenkar 2004). This has led to significant knowledge spillovers from foreign to the domestic sector in the economy and rising domestic competition in turn has compelled foreign investors to seek additional markets outside China.

ii. Domestic firms' exports activity has a strong positive impact on that of foreign firms. The exports literature has been largely preoccupied in examining exports spillovers effects from foreign to domestic firms and has neglected the possibility of domestic firms' export activities acting as a source of demonstration effects on foreign firms. The research shows that in a liberalizing host country like India, foreign firms' export-intensity is strongly dependent on that of domestic firms. From this it follows that government policies aimed at motivating foreign firms to undertake export activities has to be preceded by the emphasis on domestic firms exports activities. 
iii. The export-orientation of foreign firms has changed positively following the adoption of an outward looking regime since 1991. The new policy regime seems to have stimulated exports activities of foreign affiliates by producing an exportfriendly business atmosphere. Nevertheless, the Indian government needs to be both proactive and cautious so far as the nature and composition of exports, the propensity for which is keenly opted for by the foreign affiliates. The overwhelming emphasis upon exporting mineral products following preliminary processing is an ominous sign that potentially reduces the host country as a mere 'colony' or 'periphery', albeit in its modern guise.

iv. It has been observed that foreign affiliates in India have significantly lower export intensities in R\&D- and advertising-intensive industries. The host country policies may target foreign firms operating in these industries so as to induce a competitive domestic enterprise.

v. Local competition seems to have played a negative role in the export orientation of foreign affiliates. Foreign firms are likely to focus more on domestic market when they are faced with rising local competition in the domestic market. However, this result is subject to the bias generated from collinearity problem.

Although the presence and role of foreign manufacturing affiliates in India are yet to be broad-based, the potential manifestation of these as essentially firms that enhance global market share through using host country resources (by competing out domestic firms and/or exporting virtually little-processed raw material), can be a matter of serious policy concern. Before allowing for all possible provisions to render the market-seeking FDI into export-oriented one, the objective conditions/ constraints within which domestic firms function (and often succeed in the export market!) need to be carefully assessed. The basic premise of this paper entails that the central aim of a macro/ trade policy shift must be cautious and vigilant. As we note from this limited exercise, the nature and composition of the foreign affiliates' export portfolio could neither favour domestic firms to upgrade nor adding value at the host country site. India's recent and rather nascent exposure to the operation of foreign affiliates points to a set of tendencies which are distinctly different from (even, at times quite opposite to) experiences of oft-cited countries. This paper (though at this preliminary stage of analysis) establishes that the Indian domestic firms can rise to the occasion of facing the challenge of competitiveness (and, hence, a share in the wider global market, if not expanding the domestic presence itself through various market expansion strategies) that the presence of foreign affiliates can pose. Policy lessons to be drawn need to consider these issues as well. 


\section{References}

Aggarwal, A. (2002), 'Liberalization, Multinational Enterprises and Export Performance: Evidence from Indian Manufacturing', Journal of Development Studies, 38 (3), pp. 119-137.

Bhagwati, J.N. and A.O. Krueger (Eds.) (1974), Foreign Trade Regimes and Economic Development: A Special Conference Series on Foreign Trade Regimes and Economic Development, New York: Cambridge University Press.

Blomstrom, M., A. Kokko and M. Zejan (1994), 'Host Country Competition, Labour Skills and Technology Transfer by Multinationals', Weltwirtschaftliches Archiv, 130, pp. 521-533.

CFO Asia (1999), 'Dungeons and the Dragon', March.

Chudnovsky, D. and A. López (2004), 'Transnational Corporations' Strategies and Foreign Trade Patterns in MERCOSUR Countries in the 1990s', Cambridge Journal of Economics, 28 (5), pp. 635-652.

Currie, J. and A. Harrison (1997), 'Sharing the Costs: The Impact of Trade Reform on Capital and Labor in Morocco', Journal of Labor Economics, 15 (3, part 2), pp. 544-571.

ECLAC (2004), Foreign Investment in Latin America and the Caribbean, United Nations, Santiago, Chile.

Economic Intelligence Unit (2004), Coming of Age: Multinational Companies in China, June.

Ganesh, S. (1997), 'Who is Afraid of Foreign Firms? Current Trends in FDI in India', Economic and Political Weekly, 32 (22), pp. 1265-1274.

Greene, W. (2000), Econometric Analysis, New York: Prentice-Hall.

IMF (1997), Balance of Payments Manual, Fifth Edition, IMF.

Jensen, C. (2002), 'Foreign Direct Investment, Industrial Restructuring and the Upgrading of Polish Exports', Applied Economics, 34 (2), pp. 207-217.

Krishna, P. and D. Mitra (1998), 'Trade Liberalization, Market Discipline and Productivity Growth: New Evidence from India,' Journal of Development Economics, 56 (2), pp. 447-462.

Kumar, N. (1994), 'Determinants of Export Orientation of Foreign Production by U.S. Multinationals: An Inter-Country Analysis,' Journal of International Business Studies, First Quarter, pp. 141-156.

Kumar, N. (1994), Multinational Enterprises and Industrial Organization: The Case of India, New Delhi: Sage Publications.

Kumar, N. (1998), 'Multinational Enterprises, Regional Economic Integration and ExportPlatform Production in the Host Countries: An Empirical Analysis for the US and Japanese Corporations', Weltwirtschaftliches Archiv, 134 (3), pp. 450-483.

Kumar, N. and J.P. Pradhan (2003), 'Export Competitiveness in the Knowledge-Based Industries: A Firm-Level Analysis of Indian Manufacturing', RIS Discussion Paper, No. RIS-DP\#43/2003, New Delhi.

Kumar, N. and N.S. Siddharthan (1994), 'Technology, Firm Size and Export Behaviour in Developing Countries: The Case of Indian Enterprises', Journal of Development Studies, 31 
(2), pp. 289-309.

Kumar, N. and N.S. Siddharthan (1997), Technology, Market Structure and Internationalisation, Routledge: New York.

Leichenko, R.M. and R.A. Erickson (1997), 'Foreign Direct Investment and State Export Performance', Journal of Regional Science, 37 (2), pp. 307-329.

Liu, X. and C. Shu (2003), 'Determinants of Export Performance: Evidence from Chinese Industries', Economics of Planning, 36 (1), pp. 45-67.

Liu, X., P. Burridge, and P.J.N. Sinclair (2002), 'Relationships between Economic Growth, Foreign Direct Investment and Trade: Evidence from China', Applied Economics, 34 (11), pp. 1433-1440.

Lutz, S. and O. Talavera (2004), 'Do Ukrainian Firms Benefit from FDI?', Economics of Planning, 37 (2), pp. 77-98.

MacDonald, J.M. (1994), 'Does Import Competition Force Efficient Production?', Review of Economics and Statistics, 76 (4), pp. 721-727.

OECD (1999), OECD Benchmark Definition of Foreign Direct Investment, Third Edition.

Pant, M. (1993), 'Export Performance, Transnational Corporations and the Manufacturing Sector: A Case Study of India', Indian Economic Review, 28 (1), pp. 41-54.

Pradhan, R. P. (2005-06), 'FDI in the Globalization Era: Chinese and Indian Experiences', Prajnan, 34(4), pp. 323-343.

Ramstetter, E.D. (1999), 'Comparisons of Foreign Multinationals and Local Firms in Asian Manufacturing over Time', Asian Economic Journal, 13 (2), pp. 163-203.

Ramstetter, E.D. (1999), 'Trade Propensities and Foreign Ownership Shares in Indonesian Manufacturing', Bulletin of Indonesian Economic Studies, 35 (2), pp. 43-66.

Rasiah, R. (2004), 'Exports and Technological Capabilities: A Study of Foreign and Local Firms in the Electronics Industry in Malaysia, the Philippines and Thailand', European Journal of Development Research, 16 (3), pp. 587-623.

Roberts, M. and J. Tybout (1996), Industrial Evolution in Developing Countries: Micro Patterns of Turnover, Productivity and Market Structure, New York: Oxford University Press.

Saggi, K. (1999), 'Trade, Foreign Direct Investment, and International Technology Transfer: A Survey', Policy Research Working Paper, No. 2349, The World Bank.

Shenkar, O. (2004), The Chinese Century: The Rising Chinese Economy and Its Impact on the Global Economy, the Balance of Power, and Your Job, Wharton School Publishing.

Siddharthan, N.S. and S. Nollen (2004), 'MNE Affiliation, Firm Size and Exports Revisited: A Study of Information Technology Firms in India', Journal of Development Studies, 40 (6), pp. 146-168.

Sun, H. (2001), 'Foreign Direct Investment and Regional Export Performance in China', Journal of Regional Science, 41 (2), pp. 317-336.

UNCTAD (1993), Explaining and Forecasting Regional Flows of Foreign Direct Investment, United Nations, New York. 
UNCTAD (2002), The World Investment Report 2002: Transnational Corporations and Export Competitiveness, United Nations, New York and Geneva.

UNCTAD (2003), The World Investment Report 2003: FDI Policies for Development: National and International Perspectives, United Nations Publications, Geneva.

Woodward, D.P. and R.J. Rolfe (1993), 'The Location of Export-Oriented Foreign Direct Investment in the Caribbean Basin', Journal of International Business Studies, First Quarter, pp. 121-144.

Wooldridge, J.M. (2002), Econometric Analysis of Cross Section and Panel Data, Cambridge, MA: MIT Press. 


\section{Appendix Tables}

Table-A1

List of Firms Classified as Foreign-owned due to their affiliation to Foreign Groups

\begin{tabular}{|c|c|}
\hline Company Name & Ownership group \\
\hline Assam Carbon Products Ltd. & Private (Foreign) \\
\hline Beck India Ltd. & Private (Foreign) \\
\hline $\begin{array}{l}\text { Bombay Drugs \& Pharmas Ltd. } \\
\text { [Merged] }\end{array}$ & Private (Foreign) \\
\hline Charminar Breweries Ltd. [Merged] & Chhabria M.R. Group \\
\hline Consortex Karl Doelitzsch (India) Ltd. & Private (Foreign) \\
\hline Daewoo Motors India Ltd. & Private (Foreign) \\
\hline Falcon Tyres Ltd. & Chhabria M.R. Group \\
\hline Haryana Breweries Ltd. [Merged] & Chhabria M.R. Group \\
\hline Hind Lever Chemicals Ltd. [Merged] & Uni Lever (F) Group \\
\hline $\begin{array}{l}\text { I T C Bhadrachalam Paperboards Ltd. } \\
\text { [Merged] }\end{array}$ & I.T.C. (F) Group \\
\hline I T C Ltd. & I.T.C. (F) Group \\
\hline Indo Rama Textiles Ltd. & Uniworth (Indo Rama ) Group \\
\hline International Bestfoods Ltd. [Merged] & Uni Lever (F) Group \\
\hline Ion Exchange (India) Ltd. & Private (Foreign) \\
\hline Ispat Profiles India Ltd. & Ispat (Mittals) Group \\
\hline Lanxess A B S Ltd. & Private (Foreign) \\
\hline Lotus Chocolate Co. Ltd. & Private (Foreign) \\
\hline Mather \& Platt Fire Systems Ltd. & Chhabria M.R. Group \\
\hline Moser Baer India Ltd. & Moser Baer (F) Group \\
\hline Mount Everest Mineral Water Ltd. & Private (Foreign) \\
\hline Namburnadi Tea Co. Ltd. & Mehta Mahendra Group \\
\hline Narmada Gelatines Ltd. & Chhabria M.R. Group \\
\hline Pampasar Distillery Ltd. [Merged] & Chhabria M.R. Group \\
\hline Raashi Fertilizers Ltd. & NRI Business Houses \\
\hline Ray Ban Sun Optics India Ltd. & Private (Foreign) \\
\hline Rochees Breweries Ltd. & Chhabria M.R. Group \\
\hline Rossell Tea Ltd. & Private (Foreign) \\
\hline S B International Ltd. & Private (Foreign) \\
\hline Schenectady Herdillia Ltd. & Private (Foreign) \\
\hline Sica Breweries Ltd. [Merged] & Chhabria M.R. Group \\
\hline Skol Breweries Ltd. [Merged] & Chhabria M.R. Group \\
\hline Strides Arcolab Ltd. & Private (Foreign) \\
\hline Sulzer India Ltd. & Private (Foreign) \\
\hline Tasty Bite Eatables Ltd. & Private (Foreign) \\
\hline Uniworth Textiles Ltd. & Uniworth (Indo Rama ) Group \\
\hline
\end{tabular}




\begin{tabular}{|l|c|}
\hline \multicolumn{1}{|c|}{ Company Name } & Ownership group \\
\hline Vanavil Dyes \& Chemicals Ltd. & Private (Foreign) \\
\hline Vashisti Detergents Ltd. & Uni Lever (F) Group \\
\hline Wimco Ltd. & Wimco (Swedish Match) (F) Group \\
\hline
\end{tabular}

Source: Prowess Database, 2005.

Table-A2

Number of Firms in the Sample

\begin{tabular}{|c|c|c|c|}
\hline \multirow{2}{*}{ ISIC Rev.3 Code } & \multicolumn{3}{|c|}{ Number of Firms } \\
\cline { 2 - 4 } & Domestic & Foreign & Total \\
\hline$(1)$ & $(2)$ & $(3)$ & $(4)$ \\
\hline 15 & 618 & 64 & 682 \\
\hline 17 & 660 & 36 & 696 \\
\hline 20 & 201 & 13 & 214 \\
\hline 23 & 38 & 8 & 46 \\
\hline 24 & 654 & 79 & 733 \\
\hline 25 & 274 & 25 & 299 \\
\hline 26 & 180 & 21 & 201 \\
\hline 27 & 573 & 41 & 614 \\
\hline 29 & 233 & 69 & 302 \\
\hline 30 & 48 & 4 & 52 \\
\hline 31 & 178 & 24 & 202 \\
\hline 32 & 114 & 21 & 135 \\
\hline 33 & 57 & 12 & 69 \\
\hline 34 & 192 & 48 & 240 \\
\hline 35 & 36 & 3 & 39 \\
\hline 36 & 105 & 2 & 107 \\
\hline 2423 & 292 & 52 & 4975 \\
\hline Grand Total & 4453 & 522 & \\
\hline & & & \\
\hline
\end{tabular}


Table-A3

Results from Collinearity Analysis I

\begin{tabular}{|l|c|c|c|}
\hline \multicolumn{1}{|c|}{ Independent Variable } & \multicolumn{3}{|c|}{ Collinearity Statistics } \\
\cline { 2 - 4 } & VIF & Tolerance & R-Squared \\
\hline \multicolumn{1}{|c|}{ (1) } & $(2)$ & $(3)$ & $(4)$ \\
\hline DMKT & 4.79 & 0.2086 & 0.7914 \\
\hline GDMKT & 1.3 & 0.7712 & 0.2288 \\
\hline DCOM & 10.48 & 0.0954 & 0.9046 \\
\hline DEXINT & 13.52 & 0.074 & 0.926 \\
\hline IMCOM & 4.15 & 0.2407 & 0.7593 \\
\hline RDINT & 4.33 & 0.231 & 0.769 \\
\hline ADVINT & 6.44 & 0.1553 & 0.8447 \\
\hline AGE & 5.27 & 0.1899 & 0.8101 \\
\hline Indum2 & 8.61 & 0.1162 & 0.8838 \\
\hline Indum3 & 3.7 & 0.2699 & 0.7301 \\
\hline Indum4 & 14.35 & 0.0697 & 0.9303 \\
\hline Indum5 & 3.6 & 0.2775 & 0.7225 \\
\hline Indum6 & 3.47 & 0.2885 & 0.7115 \\
\hline Indum7 & 3.65 & 0.2736 & 0.7264 \\
\hline Indum8 & 5.69 & 0.1757 & 0.8243 \\
\hline Indum9 & 3.64 & 0.2751 & 0.7249 \\
\hline Indum10 & 3.46 & 0.2887 & 0.7113 \\
\hline Indum11 & 4.78 & 0.2092 & 0.7908 \\
\hline Indum12 & 7.27 & 0.1375 & 0.8625 \\
\hline Indum13 & 3.66 & 0.2729 & 0.7271 \\
\hline Indum14 & 7.23 & 0.1383 & 0.8617 \\
\hline
\end{tabular}

Mean VIF 5.88

Note: R-Squared is from auxiliary regression. Indum denotes industries dummies. 
Table-A4

Results from Collinearity Analysis II

\begin{tabular}{|l|c|c|c|}
\hline \multicolumn{1}{|c|}{ Independent Variable } & \multicolumn{3}{|c|}{ Collinearity Statistics } \\
\cline { 2 - 3 } & VIF & Tolerance & R-Squared \\
\hline DMKT & $(2)$ & $(3)$ & $(4)$ \\
\hline GMKT & 4.82 & 0.207 & 0.793 \\
\hline DCOM & 1.33 & 0.755 & 0.245 \\
\hline DEXINT & 12.68 & 0.079 & 0.921 \\
\hline IMCOM & 13.87 & 0.072 & 0.928 \\
\hline PSDUM & 4.16 & 0.241 & 0.759 \\
\hline RDINT & 2.12 & 0.471 & 0.529 \\
\hline ADVINT & 4.33 & 0.231 & 0.769 \\
\hline AGE & 6.71 & 0.149 & 0.851 \\
\hline Indum2 & 5.86 & 0.171 & 0.829 \\
\hline Indum3 & 8.65 & 0.116 & 0.884 \\
\hline Indum4 & 4.34 & 0.230 & 0.770 \\
\hline Indum5 & 19.05 & 0.053 & 0.948 \\
\hline Indum6 & 3.89 & 0.257 & 0.743 \\
\hline Indum7 & 3.9 & 0.257 & 0.744 \\
\hline Indum8 & 4.22 & 0.237 & 0.763 \\
\hline Indum9 & 6.19 & 0.162 & 0.839 \\
\hline Indum10 & 3.98 & 0.251 & 0.749 \\
\hline Indum11 & 3.82 & 0.262 & 0.738 \\
\hline Indum12 & 5.75 & 0.174 & 0.826 \\
\hline Indum13 & 8.37 & 0.120 & 0.881 \\
\hline Indum14 & 4.06 & 0.246 & 0.754 \\
\hline & 7.29 & 0.137 & \\
\hline Mean VIF & & & 0.863 \\
\hline
\end{tabular}

Mean VIF 6.34

Note: R-Squared is from auxiliary regression. Indum denotes industries dummies. 


\section{List of ISID Working Papers}

WP2006/07 Overseas Acquisition Versus Greenfield Foreign Investment: Which Internationalization Strategy is better for Indian Pharmaceutical Enterprises? Jaya Prakash Pradhan and Abhinav Alakshendra.

WP2006/06 Some features of Migration and Labour Mobility in the Leather Accessories Manufacture in India: A Study of the Informal Sector Industry in Dharavi, Mumbai, Jesim Pais.

WP2006/05 Global Competitiveness of Indian Pharmaceutical Industry: Trends and Strategies, Jaya Prakash Pradhan.

WP2006/04 Tourism Employment: An Analysis of Foreign Tourism in India, Jesim Pais.

WP2006/03 Adoption of Improved Technology in India's Small-scale Industries: Evidences from a Field Survey, Partha Pratim Sahu.

WP2006/02 Strengthening Intellectual Property Rights Globally: Impact on India's Pharmaceutical Exports, Jaya Prakash Pradhan.

WP2006/01 Towards Understanding the State-wise Distribution of Foreign Direct Investments in the Post-Liberalisation Period, $K S$ Chalapati Rao and $M R$ Murthy.

WP2005/03* Indian Stock Market: 2004-05 - Some Issues, K S Chalapati Rao and KV K Ranganathan.

WP2005/02* Workers in a Globalising World: Some Perspectives from India, T S Papola.

WP2005/01 Emerging Structure of Indian Economy: Implications of Growing Intersectoral Imbalances, T S Papola.

WP2004/13 Economic History of Tobacco Production in India, S K Goyal, Pratap C Biswal and $K V K$ Ranganathan.

WP2004/12 Potential Impact of Supply-side Actions, S K Goyal, Pratap C Biswal and KV K Ranganathan.

WP2004/11* Is Growth Sans Industrialisation Substainable? ISID Foundation Day Lecture, GS Bhalla.

WP2004/10 Labour: Down and Out, T S Papola and A N Sharma.

WP2004/09* Foreign Trade Policy: Content and Coverage, T P Bhat.

WP2004/08* National Trade Policy: What it Implies? T P Bhat.

WP2004/07* WTO Negotiations Back on Track, T P Bhat.

WP2004/06* Chinese Perspective of Bilateral Trade with India, T P Bhat.

WP2004/05* A Challenge for Social Scientist, $S$ K Goyal. 
WP2004/04* Foreign Portfolio Investments and the Indian Stock Market Boom of 2003-04: A Note, K S Chalapati Rao.

WP2004/03* Wavelet Analysis of the Bombay Stock Exchange Index, Pratap C Biswal, B Kammaiah and Prasanta K Panigrahi.

WP2004/02 Company Size and Effective Corporate Tax Rate: A Study on Indian Private Manufacturing Companies, Atulan Guha.

WP2004/01* Anti-dumping - Containment and Reform, T P Bhat.

WP2003/10* Government Procurement Agreement: Negotiating Position for India, T P Bhat.

WP2003/09* Heralding of Asian Giant Trade Block, T P Bhat.

WP2003/08* China the Victim of Anti-dumping Action, T P Bhat.

WP2003/07* Cost of Public Holidays, T P Bhat.

WP2003/06* India and China on New Horizon, T P Bhat.

WP2003/05 Asymmetrics in Interest Rate Sensitivity of Capital Flows: Some Empirical Evidences, Atulan Guha.

WP2003/04* Collapse of Cancum Meet, T P Bhat.

WP2003/03 Free-float Sensex is Better Index, Pratap C Biswal.

WP2003/02* Globalization of Anti-dumping and its Impact, T P Bhat.

WP2003/01 IRAQ: Some Serious Concerns, S K Goyal.

WP2002/01* An Overview of the Indian Stock Market with Emphasis on Ownership Pattern of Listed Companies, K S Chalapati Rao.

WP2001/02* $\quad$ Stock Market, K S Chalapati Rao.

WP2001/01* Washington Consensus and India: Experience of the Last Decade, S K Goyal and K S Chalapati Rao.

WP2000/02 A Reform of Corporate Statistics: Some Suggestions, K S Chalapati Rao and Nagesh Kumar.

WP2000/01* Stock Market, K S Chalapati Rao.

WP1999/07* Some Aspects of the Indian Stock Market in the Post-Liberalisation Period, $K$ $S$ Chalapati Rao, M R Murthy and KV K Ranganathan.

WP1999/06* Foreign Institutional Investments and the Indian Stock Market, K S Chalapati Rao, KV K Ranganathan and M R Murthy.

WP1999/05* Foreign Direct Investments in the Post-Liberalisation Period: An Overview, K S Chalapati Rao, M R Murthy and KV K Ranganathan.

* Already Published. Most of the working papers are downloadable from the institute's website: http://isidev.nic.in/ or http://isid.org.in/ 


\begin{abstract}
About the ISID
The Institute for Studies in Industrial Development (ISID), successor to the Corporate Studies Group (CSG), is a national-level policy research organization in the public domain and is affiliated to the Indian Council of Social Science Research (ICSSR). Developing on the initial strength of studying India's industrial regulations, ISID has gained varied expertise in the analysis of the issues thrown up by the changing policy environment. The Institute's research and academic activities are organized under the following broad thematic areas:
\end{abstract}

Industrial Development: Complementarity and performance of different sectors (public, private, FDI, cooperative, SMEs, etc.); trends, structures and performance of Indian industries in the context of globalisation; locational aspects of industry in the context of balanced regional development.

Corporate Sector: Ownership structures; finance; mergers and acquisitions; efficacy of regulatory systems and other means of policy intervention; trends and changes in the Indian corporate sector in the background of global developments in corporate governance, integration and competitiveness.

Trade, Investment and Technology: Trade policy reforms, WTO, composition and direction of trade, import intensity of exports, regional and bilateral trade, foreign investment, technology imports, $\mathrm{R} \& \mathrm{D}$ and patents.

Employment, Labour and Social Sector: Growth and structure of employment; impact of economic reforms and globalisation; trade and employment, labour regulation, social protection, health, education, etc.

Media Studies: Use of modern multimedia techniques for effective, wider and focused dissemination of social science research and promote public debates.

ISID has developed databases on various aspects of the Indian economy, particularly concerning industry and the corporate sector. It has created On-line Indexes of Indian Social Science Journals (OLI) and Press Clippings on diverse social science subjects. These have been widely acclaimed as valuable sources of information for researchers studying India's socio-economic development.

Institute for Studies in Industrial Development 4, Institutional Area, Vasant Kunj, New Delhi - 110 070, INDIA Phone/Fax: +91 112689 1111; E-mail: info@ vidur.delhi.nic.in 